\title{
ANÁLISE DA INFLUÊNCIA DO ULTRA-SOM TERAPÊUTICO NA PENETRAÇÃO TRANSCUTÂNEA DE DICLOFENACO SÓDICO EM HUMANOS SADIOS
}

Giovana de Cássia Rosim

Dissertação apresentada ao Programa de Pós-Graduação Interunidades Bioengenharia - Escola de Engenharia de São Carlos / Faculdade de Medicina de Ribeirão Preto / Instituto de Química de São Carlos da Universidade de São Paulo, como parte dos requisitos para obtenção do título de Mestre em Bioengenharia.

ORIENTADOR: Prof. Dr.Cláudio Henrique Barbieri

São Carlos 
R819a

Rosim, Giovana de Cássia

Análise da influência do ultra-som terapêutico na penetração transcutânea de diclofenaco sódico em humanos sadios / Giovana de Cássia Rosim. -- São Carlos, 2003.

Dissertação (Mestrado) -- Escola de Engenharia de São Carlos/Faculdade de Medicina de Ribeirão Preto/Instituto de Química de São Carlos-Universidade de São Paulo, 2003 Área Interunidades: Bioengenharia.

Orientador: Prof. Dr. Cláudio Henrique Barbieri.

1. Ultra-som terapêtico. 2. Transmissão transcutânea. 3. Sonoforese. 4. Diclofenaco sódico. 5. Gel tópico.

6. Cromatografia líquida de alta eficiência. I. Título 


\section{AGRADECIMENTOS}

A DEUS, que conhece o meu caminho e guia os meus passos.

Aos meus pais e irmã pelo amor, compreensão, incentivo, gratidão e fidelidade, virtudes que são ensinadas muito mais pelo exemplo do que pelos livros.

Ao Prof. Dr. Cláudio Henrique Barbieri, exemplo de professor, pela orientação, paciência e ensinamentos.

Ao Prof. Dr. Nilton Mazzer, à fisioterapeuta Marisa C. R. Fonseca e à terapeuta ocupacional Valéria M. C. Elui, que fizeram parte do início da minha vida profissional no Programa de Aprimoramento em Ortopedia e Traumatologia do HCFMRP - USP.

Ao Prof. Dr. Fernando Mauro Lanças, que permitiu que uma insistente fisioterapeuta aprendesse a difícil cromatografia líquida de alta eficiência no Instituto de Química de São Carlos.

À química Cristina Alves Lacerda, pela paciência, ensinamentos e finais de semana empenhados no auxílio para a realização da técnica de cromatografia.

Ao Prof. Antônio Dorival Campos, do Departamento de Medicina Social do HCFMRP-USP, pela valiosa colaboração na análise estatística dos dados.

Às secretárias do Programa de Pós-Graduação Interunidades Bioengenharia, Janete, Fátima e Terezinha, pela paciência e colaboração. 
Ao Laboratório de Análises Clínicas Eugênia Cabianca, principalmente à Eugênia, exemplo de profissionalismo e prudência; e às meninas do laboratório, Luciana, Morgana, Aline, Juliana e Rosangela, pelo bom humor e colaboração.

Aos voluntários, pela disponibilidade e contribuição para a ciência.

À NOVARTIS PHARMA BRASIL, que gentilmente forneceu o padrão analítico do diclofenaco sódico.

À QUARK Produtos Médicos, pelo empréstimo do equipamento de ultra-som.

Ao Fernando, pelo carinho, pelos bons momentos e por me tirar da frente do computador.

A todos que colaboraram direta ou indiretamente para a realização deste trabalho. 
SUMÁRIO

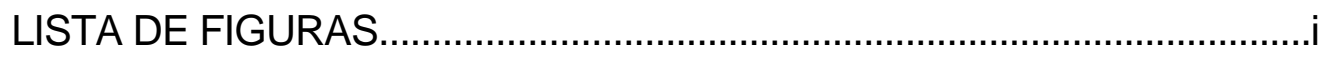

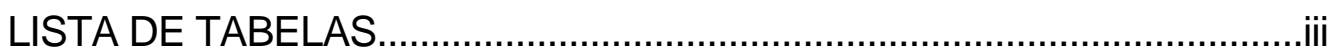

LISTA DE ABREVIATURAS E SIGLAS......................................................

LISTA DE SÍMBOLOS.................................................................................

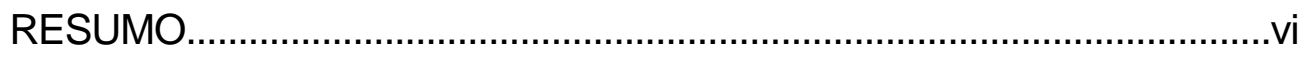

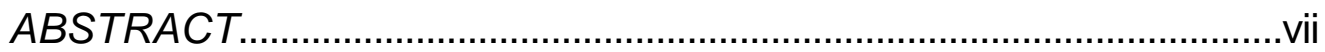

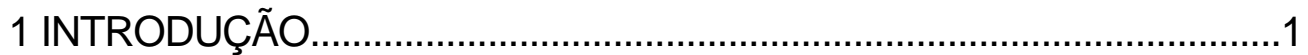

1.1 O ultra-som terapêutico...........................................................................

1.1.1 Princípios eletro-físicos .....................................................................

1.1.2 Efeitos físicos e fisiológicos do ultra-som............................................

1.2 Sonoforese ou fonoforese.....................................................................

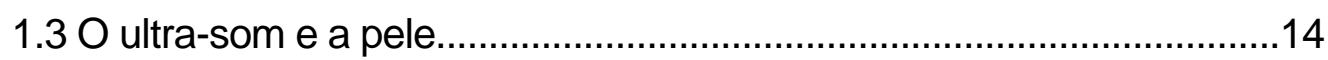

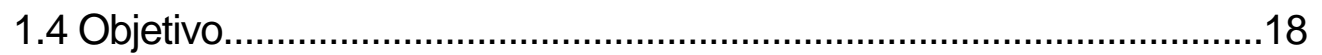

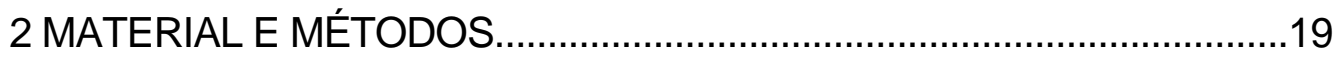

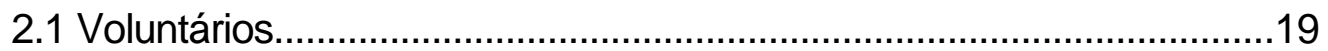

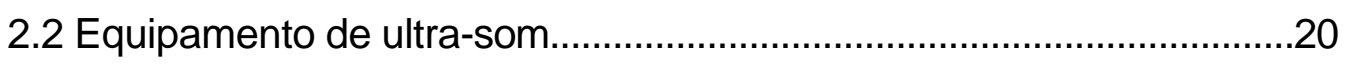

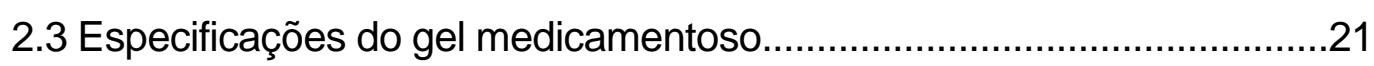

2.4 Aplicação do ultra-som e do Voltaren Emulge ${ }^{\circledR}$......................................21

2.5 Metodologia analítica e validação.........................................................24

2.5.1 Equipamento e condições cromatográficas.......................................24

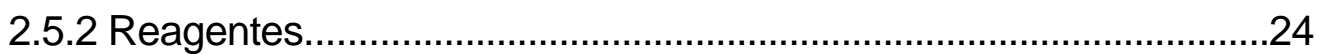

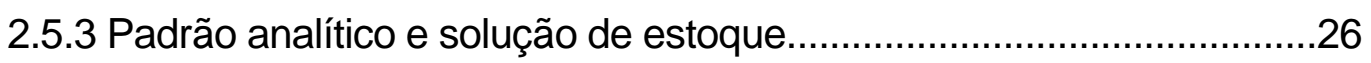

2.5.4 Procedimentos de extração do diclofenaco sódico do plasma..............26

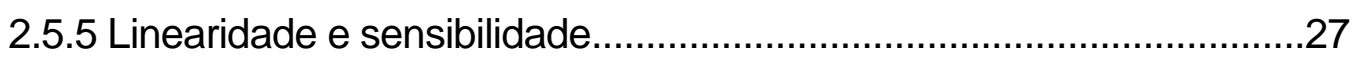

2.5.6 Precisão intra-dia e inter-dia e repetibilidade......................................29

2.5.7 Taxa de Recuperação......................................................................

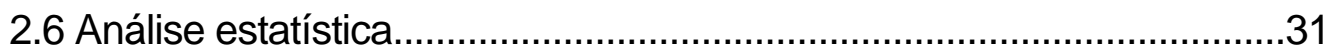

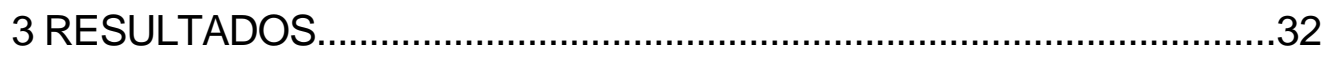

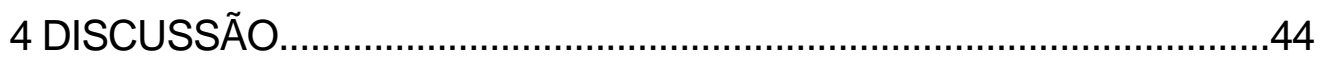

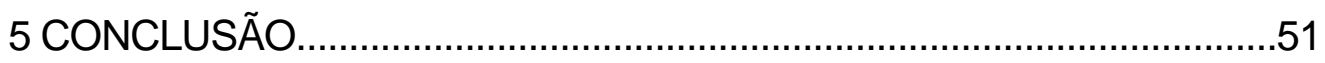


ANEXOS.

.52

REFERÊNCIAS BIBLIOGRÁFICAS

.58 


\section{LISTA DE FIGURAS}

FIGURA 01 - Feixe ultra-sônico cilíndrico irregular no campo próximo tornando-se mais regular no campo distante. .3

FIGURA 02 - Ultra-som de onda contínua (a). Ultra-som pulsado (b), ligado durante $x$ segundos e desligado durante y segundos.

FIGURA 03 - Reflexão e refração a partir de um ângulo de incidência de $90^{\circ}$ 4

FIGURA 04 - Extração do sangue de veias do antebraço dos voluntários. .20

FIGURA 05 - Determinação da área de aplicação de $225 \mathrm{~cm}^{2}(15 \times 15 \mathrm{~cm})$ de cada lado da região dorsal dos voluntários. .22

FIGURA 06 - Aplicação do ultra-som nas áreas pré-determinadas utilizando gel comum para contato e acoplamento. 22

FIGURA 07 - Mensuração de 2,5 g de Voltaren Emulge ${ }^{\circledR}$ de cada lado da região dorsal... 23

FIGURA 08 - Aplicação do Voltaren Emulge ${ }^{\circledR}$ nas mesmas áreas. .23

FIGURA 09 - Equipamento de cromatografia líquida. A - Bomba;

B - Detector; C - Forno com a coluna dentro; D - Registrador.

FIGURA 10 - Detalhes da coluna cromatográfica dentro do forno $(A)$ e do injetor (B) 25

FIGURA 11 - Curva de extração concentração x área (coeficiente de relação da reta 0,999566$)$ para concentrações conhecidas do padrão analítico do diclofenaco sódico. 28

FIGURA 12 - Cromatograma correspondente à amostra de sangue coletada previamente à aplicação do ultra-som e do Voltaren Emulge ${ }^{\circledR}$. Notar a ausência de pico em 15 minutos

FIGURA 13 - Cromatograma correspondente à amostra de sangue coletada 60 minutos após a aplicação do ultra-som e do Voltaren Emulge ${ }^{\circledR}$ (pico D: diclofenaco). 
FIGURA 14 - Cromatograma correspondente à amostra de sangue coletada 120 minutos após a aplicação do ultra-som e do Voltaren Emulgel ${ }^{\circledR}$ (pico D: diclofenaco) 35

FIGURA 15 - Cromatograma correspondente à amostra de sangue coletada 180 minutos após a aplicação do ultra-som e do Voltaren Emulge ${ }^{\circledR}$ (pico D: diclofenaco). 36

FIGURA 16 - Cromatograma correspondente à amostra de plasma branco adicionada do padrão analítico do diclofenaco $(0,3 \mu \mathrm{g} / \mathrm{ml}$ da solução padrão de estoque) (pico D: diclofenaco). .37 FIGURA 17 - Comparação dos resultados dos grupos A e B a partir dos resultados obtidos das amostras coletadas após 60 minutos do procedimento. $\mathrm{p}=0,01$ 40

FIGURA 18 - Comparação dos resultados dos grupos A e B a partir dos resultados das amostras obtidas após 120 minutos de procedimento. $\mathrm{p}=0,01$. 41

FIGURA 19 - Comparação dos resultados dos grupos A e B a partir dos resultados obtidos das amostras coletadas após 180 minutos do procedimento. $p=0,16$ .42

FIGURA 20 - Comparação dos resultados somente do Grupo A obtidos das amostras coletadas após 60,120 e 180 minutos do procedimento. $\mathrm{p}=0,11$. .43

FIGURA 21 - Comparação dos resultados somente do Grupo B obtidos das amostras coletadas após 60,120 e 180 minutos do procedimento. $\mathrm{p}=0,22$. .43 


\section{LISTA DE TABELAS}

TABELA 01 - Transmissividade de formulações tópicas em relação à água deionizada. . .9

TABELA 02 - Valores das áreas das curvas de extração do diclofenaco sódico (variação, média e desvio padrão) do plasma preparado, conforme as concentrações conhecidas do padrão analítico. 28

TABELA 03 - Precisão intra-dia (em um mesmo dia) e inter-dia (entre diferentes dias)

TABELA 04 - Taxa de recuperação, de acordo com as concentrações conhecidas do diclofenaco sódico extraído do plasma e dissolvido na fase móvel. 30

TABELA 05 - Valores da área sob o pico do diclofenaco e correspondentes valores da massa plasmática, obtidos a partir das amostras de plasma coletadas após 60 minutos do procedimento. 40

TABELA 06 - Valores da área sob o pico do diclofenaco e correspondentes valores da massa plasmática, obtidos a partir das amostras de plasma coletadas após 120 minutos do procedimento.

TABELA 07 - Valores da área sob o pico do diclofenaco e correspondentes valores da massa plasmática, obtidos a partir das amostras de plasma coletadas após 180 minutos do procedimento 42 


\section{LISTA DE ABREVIATURAS E SIGLAS}

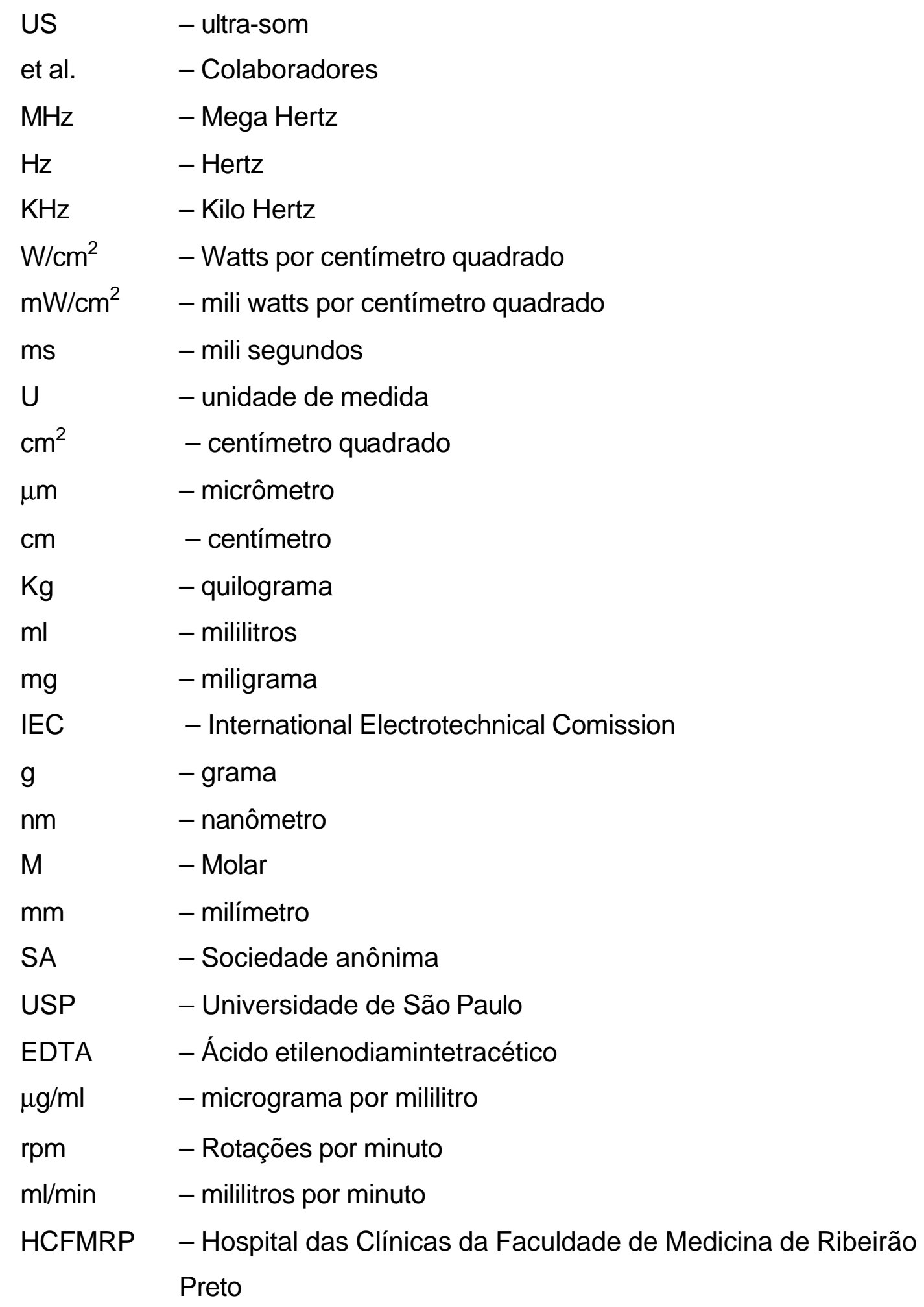




\section{LISTA DE SÍMBOLOS}

$\begin{array}{ll}{ }^{\circ} & \text { - Graus } \\ { }^{\circ} \mathrm{C} & \text { - Graus Celsius } \\ \% & \text { - porcentagem } \\ - & \text { - menos } \\ \mathrm{p} & \text { - valor ou nível de significância } \\ < & \text { - menor }\end{array}$




\section{RESUMO}

A influência do ultra-som terapêutico na transmissão transcutânea (sonoforese) do diclofenaco sódico como gel tópico $\left(\right.$ Voltaren Emulge ${ }^{\circledR}$ ) foi investigada em 14 voluntários humanos sadios (dez mulheres, quatro homens; 26,4 anos de idade, $62 \mathrm{Kg}$ de peso corporal e 1,7 m de altura, em média). Foi realizada irradiação ultra-sônica prévia da pele (modo contínuo, $1 \mathrm{MHz}$ de freqüência, intensidade de $0,5 \mathrm{~W} / \mathrm{cm}^{2}$ ) por 5 minutos em duas áreas de $225 \mathrm{~cm}^{2}(15 \times 15 \mathrm{~cm})$ de cada lado da região dorsal dos voluntários usando um gel comum para acoplamento do cabeçote, com subseqüente aplicação do gel de diclofenaco (2,5 g) em cada uma das áreas prédeterminadas e deixado por três horas. Os mesmos voluntários participaram desse procedimento duas vezes com um mês de intervalo, em média, sendo que na segunda vez com o equipamento desligado (procedimento placebo), para controle. Amostras de sangue $(3 \mathrm{ml})$ foram coletadas de veias do antebraço imediatamente antes e com 60, 120 e 180 minutos do procedimento, para análise da massa plasmática do diclofenaco, por meio da cromatografia líquida de alta eficiência (HPLC). Os resultados demonstraram que a massa plasmática do diclofenaco estava significativamente mais elevada $(p=0,01)$ aos 60 e 120 minutos após a irradiação com o ultra-som do que após o procedimento placebo. Dentro das condições em que este estudo foi realizado, os resultados permitem concluir que a irradiação prévia da pele com ultra-som terapêutico facilita a penetração transcutânea de diclofenaco sódico na forma de gel tópico.

Palavras-chave: ultra-som terapêutico; transmissão transcutânea; sonoforese; diclofenaco sódico; gel tópico; cromatografia líquida de alta eficiência. 


\section{ABSTRACT}

The influence of therapeutic ultrasound on the transdermal transmission (sonophoresis) of sodium diclofenac as a gel of topic application (Voltaren Emulge ${ }^{\circledR}$ ) was investigated in 14 human healthy volunteers (ten women, four men, 26,4 years of age, $62 \mathrm{Kg}$ of body weight and $1,7 \mathrm{~m}$ of height on average). Therapeutic ultrasound (continuous mode, $1 \mathrm{MHz}$ frequency, $\left.0,5 \mathrm{~W} / \mathrm{cm}^{2}\right)$ was applied for 5 minutes on two $225-\mathrm{cm}^{2}(15 \times 15$ $\mathrm{cm}$ ) areas on each side of the dorsum of the volunteers using ultrasound transmission gel as a coupling agent. Following ultrasonic irradiation, the gel was removed and gloves were used to apply $2,5 \mathrm{~g}$ on each two defined areas. The same volunteers participated in procedures twice at one-month interval on average, however the second time with the equipment turned off (sham procedure) for control. Blood samples $(3 \mathrm{ml})$ were withdrawn from forearm veins, near the elbow flexure, immediately before and at 60, 120 and 180 minutes from the procedure, for analysis of the plasmatic diclofenac mass by means of high performance liquid chromatography (HPLC). The results showed that the plasmatic diclofenac mass was significantly higher $(p=0,01)$ at 60 and 120 minutes following the ultrasound irradiation than the sham procedure. The results presented in this study support that therapeutic ultrasound applied prior to application of sodium diclofenac gel does lead to enhanced penetration of the drug across the skin under the conditions of the investigation.

Key words: therapeutic ultrasound; transdermal penetration; sonophoresis; sodium diclofenac; topic gel; high performance liquid chromatography. 


\section{INTRODUÇÃO}

\subsection{O ultra-som terapêutico}

O ultra-som terapêutico é um recurso amplamente utilizado em fisioterapia e medicina do esporte, para o tratamento de uma grande variedade de condições, em especial patologias músculo-esqueléticas e reumáticas, traumáticas e adquiridas. Efeitos benéficos têm sido demonstrados, por exemplo, no tratamento de úlceras varicosas (DYSON \& SUCKLING, 1978), cicatrização tendinosa (ENWEMEKA, 1989; JACKSON et al., 1991; GAN et al., 1995; BARROS Jr., 2001), reparação de lesões musculares (MENEZES et al., 1999), reparação de lesões nervosas (MONTE RASO, 2002) e na facilitação da penetração transcutânea de drogas de uso tópico, especificamente corticoesteróides (BYL et al., 1993), vasodilatadores (McELNAY et al., 1993), proteínas (MITRAGOTRI et al., 1995) e indometacina (ASANO et al., 1997).

\subsubsection{Princípios Eletro-físicos}

As ondas ultra-sônicas para fins terapêuticos são geradas quando um campo elétrico de alta freqüência (1 - $3 \mathrm{MHz}$ ) é aplicado sobre um cristal piezoelétrico, localizado no transdutor do aparelho de ultra-som, que vibra na mesma freqüência do campo, produzindo ondas acústicas de alta freqüência. A piezoeletricidade é um fenômeno natural de alguns materiais e que faz com que o cristal transforme energia elétrica em mecânica e viceversa. As ondas acústicas geradas são pobremente transmitidas através do ar, de modo que é necessário um meio acoplador, geralmente um gel condutor, entre o transdutor ultra-sônico e a superfície do corpo a ser tratada. O meio acoplador conduz a energia da onda para a pele humana e de tecido a tecido, enquanto houver um meio condutor entre eles (KANH, 1991; KLAIMAN et al., 1998). 
As ondas ultra-sônicas recebem essa denominação por se situarem fora do alcance da audição humana. A vibração mecânica se torna sonora para a audição humana com freqüências entre 16 e $20 \mathrm{~Hz}$. A vibração abaixo desse limite é chamada de infra-som e acima, de ultra-som (REED \& LOW, 2001).

A possibilidade de usar diferentes freqüências entre 1 e $3 \mathrm{MHz}$ é importante, na medida em que as freqüências mais altas $(3 \mathrm{MHz})$ são absorvidas mais rapidamente, tornando-as mais específicas para 0 tratamento de tecidos mais superficiais, enquanto que as freqüências mais baixas (1 MHz) penetram mais profundamente, devendo ser usadas para os tecidos mais profundos (DOCKER, 1987).

O feixe sonoro que sai do cabeçote de tratamento é cilíndrico e com o mesmo diâmetro do transdutor (WILLIAMS, 1987), mas não é uniforme, mesmo em um meio homogêneo. Algumas ondas se cancelam entre si, outras se reforçam, de modo que o resultado final é um padrão irregular de ondas sonoras na região próxima da face do transdutor, chamada de campo próximo, ou zona de Fresnel. Daí em diante, o campo distante, ou zona de Fraunhofer, o campo sonoro se alastra e torna-se muito mais regular porque as diferenças no percurso percorrido a partir do transdutor se tornam insignificantes com as distâncias maiores (LOW \& REED, 2001). Para fins práticos, o ultra-som terapêutico utiliza o campo próximo e é, portanto, irregular (FIGURA 1).

O ultra-som pode ser produzido sob a forma de ondas contínuas ou pulsadas. Ondas contínuas são produzidas quando o campo elétrico é aplicado de maneira contínua sobre o cristal, durante todo o período de tratamento; as ondas pulsadas são produzidas quando o campo elétrico é aplicado em pulsos, ou rajadas (HAAR, 1998). Os trens de onda para aplicação por ondas contínuas e pulsadas estão ilustrados na figura 2. 


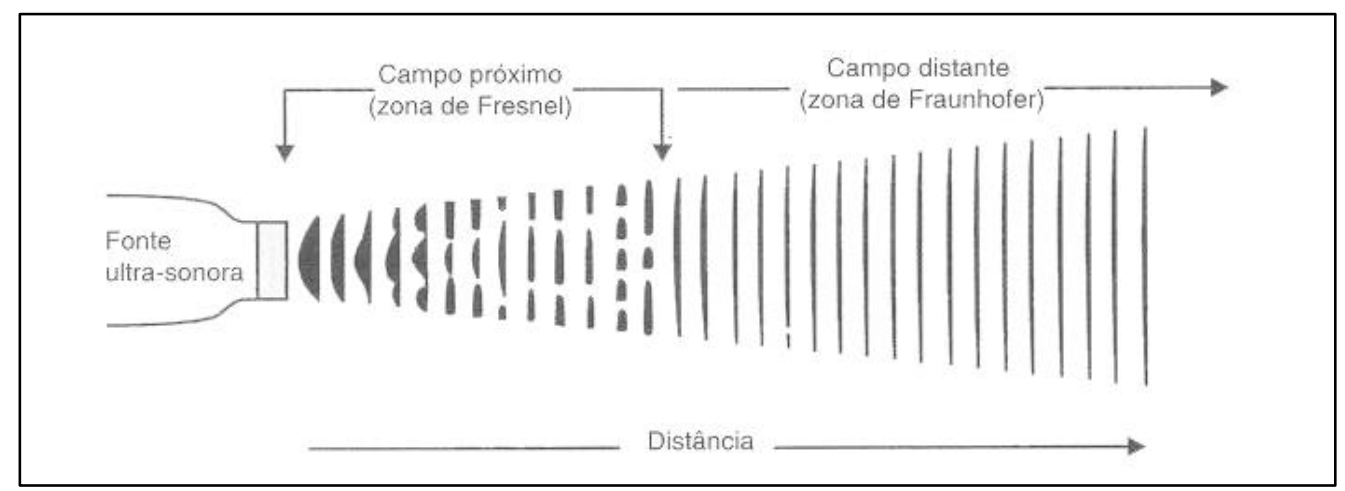

FIGURA 1 - Feixe ultra-sônico cilíndrico irregular no campo próximo tornando-se mais regular no campo distante.

Fonte: LOW \& REED (2001).

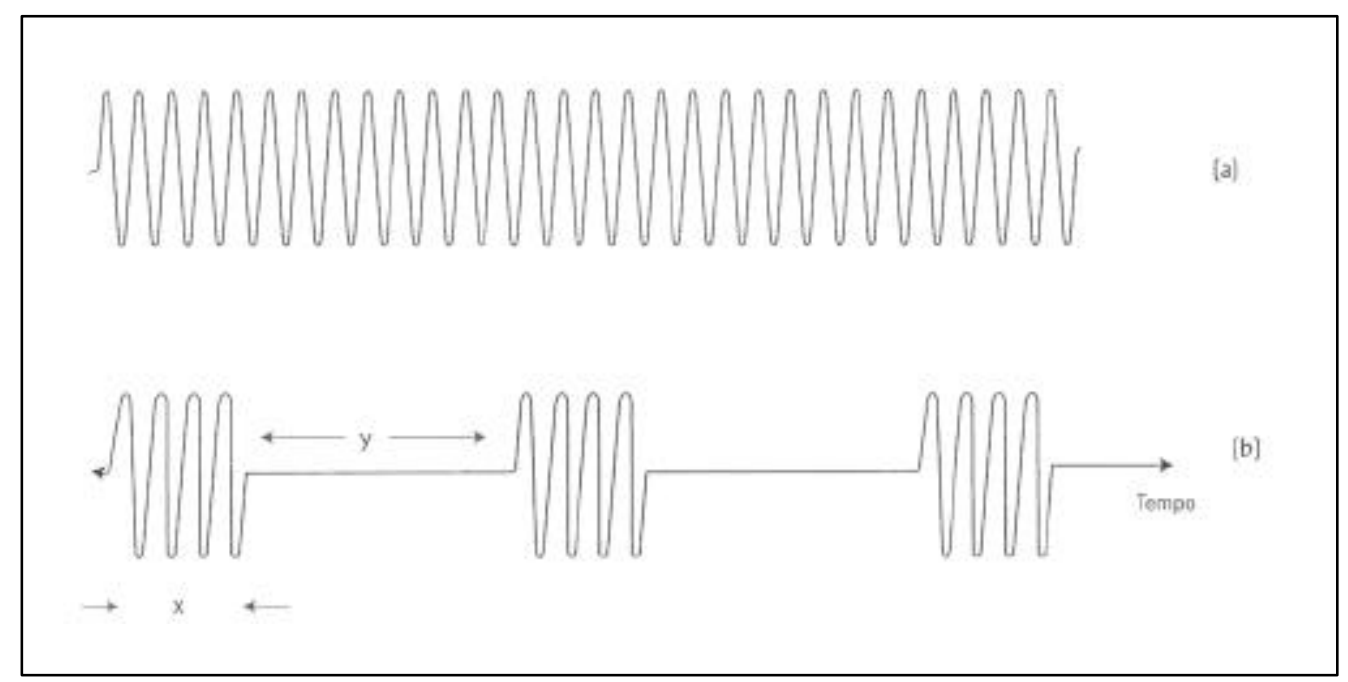

FIGURA 2 - Ultra-som de onda contínua (a). Ultra-som pulsado (b), ligado durante $x$ segundos e desligado durante y segundos.

Fonte: BAZIN \& KITCHEN (1998). 
Além de depender das diferentes freqüências $(1-3 \mathrm{MHz})$, a energia conduzida pela onda ultra-sonora também depende da impedância acústica do meio, que depende da natureza do material, ou seja, a facilidade com que as moléculas se movem umas em relação à outras, de modo que a velocidade das ondas sonoras naquele meio está relacionada a ela. A impedância acústica pode ser encontrada multiplicando-se a densidade do meio pela velocidade das ondas sonoras que passam através dele (LOW \& REED, 2001).

As ondas ultra-sonoras podem ser refletidas ou refratadas e a diferença entre as impedâncias acústicas dos materiais que são por elas atravessados é que determina a intensidade de cada uma (WILLIAMS, 1987) (FIGURA 3). A onda refletida tem um efeito adicional sobre o material irradiado, pois duas ondas, a original e a refletida, estão se deslocando em sentidos opostos, de modo que em alguns pontos elas se combinarão, produzindo uma amplitude e energia de onda maior, enquanto que em outros elas se cancelarão. Isso tende a produzir um padrão de ondas chamadas estacionárias, que são geradas nos tecidos por meio do ultra-som terapêutico e podem ter conseqüências deletérias significativas (LOW \& REED, 2001). Evita-se a formação dessas ondas através do movimento contínuo do transdutor ultra-sônico (HAAR, 1987).

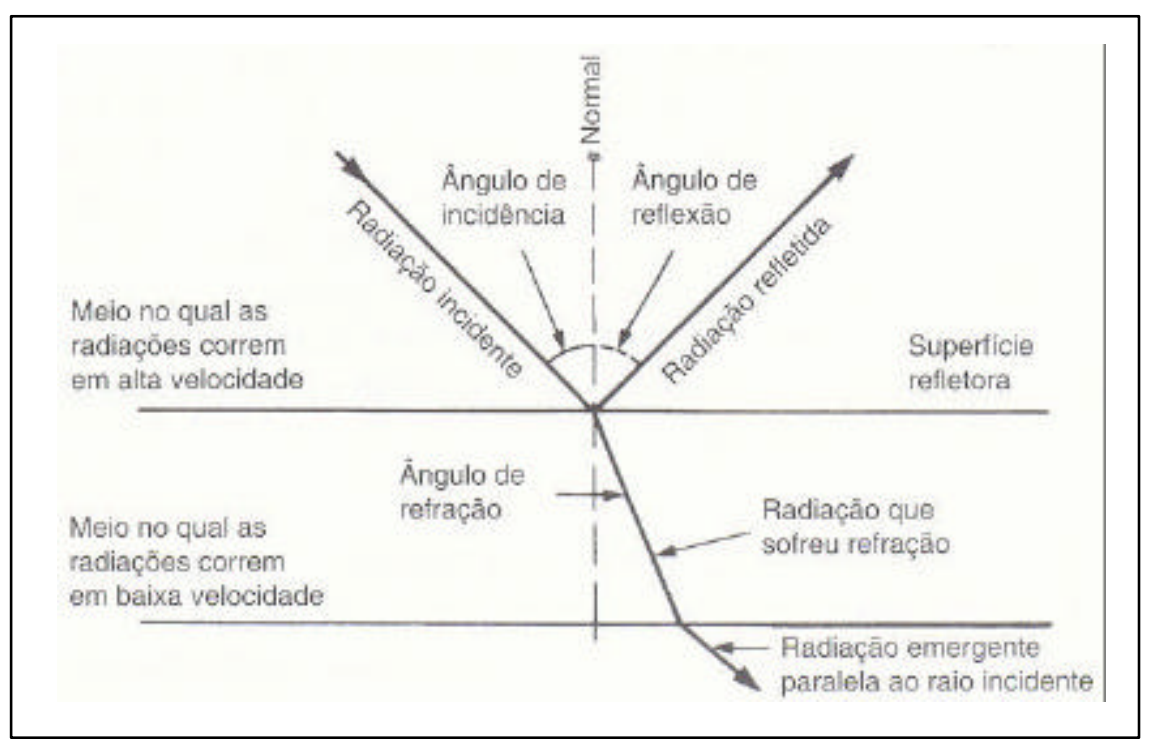

FIGURA 3 - Reflexão e refração a partir de um ângulo de incidência de 90․ . Fonte: LOW \& REED (2001). 


\subsubsection{Efeitos físicos e fisiológicos do ultra-som}

Os mecanismos de interação pelos quais o ultra-som terapêutico induz respostas clinicamente significativas nos tecidos biológicos são classificados como térmicos e não-térmicos (DYSON, 1987; KITCHEN \& PARTRIDGE, 1990; KANH, 1991; KITCHEN \& BAZIN, 1998; LOW \& REED, 2001).

\section{Efeitos térmicos}

Quando o ultra-som desloca-se através dos tecidos, como já foi discutido, parte dele é absorvido gerando calor dentro do tecido (KITCHEN \& BAZIN, 1998). A energia sonora é convertida em energia térmica proporcional à intensidade do utra-som. Se o calor não é dissipado pelos meios fisiológicos normais, ocorre aumento da temperatura local que resulta nos efeitos térmicos (LOW \& REED, 2001).

LEHMANN \& DeLATEUR` apud KITCHEN \& BAZIN (1998) afirmam que um efeito térmico biologicamente significativo pode ser obtido se a temperatura do tecido for elevada para algo entre $40 \circ \mathrm{C}$ e $45^{\circ} \mathrm{C}$ durante um período mínimo de cinco minutos. O aquecimento dos tecidos pode produzir um aumento temporário na extensibilidade de estruturas altamente colagenosas, tais como tendões, ligamentos e cápsulas articulares, diminuição da rigidez articular, redução da dor, redução do espasmo muscular e suave reação inflamatória, incluindo um aumento temporário no fluxo sanguíneo (DYSON, 1987).

Segundo LOW \& REED (2001), a alteração nos vasos sanguíneos decorrente do aquecimento da superfície é a vasodilatação que ocorre não somente para distribuir o calor adicional pelo corpo, permitindo perdas compensatórias em outras regiões, mas também para proteger a pele aquecida. Ainda segundo esses autores, a vasodilatação decorrente do calor é causada por vários outros mecanismos:

\footnotetext{
• LEHMANN, J. F.; DeLATEUR, B. J. (1982). Therapeutic Heat and Cold apud KITCHEN, S.; BAZIN, S. (1998). Eletroterapia de Clayton. São Paulo, Manole, p.237.
} 
- efeito direto sobre os capilares, arteríolas e vênulas, de natureza ainda não bem compreendida, fazendo com que todos dilatem;

- reflexo axonal disparado pela estimulação de receptores polimodais, pelo envolvimento somente de fibras nervosas aferentes;

- alteração metabólica com liberação adicional de dióxido de carbono e ácido lático, aumentando a acidez dos tecidos aquecidos, que tende a provocar vasodilatação; e

- dano protéico local, com reação inflamatória e liberação de bradicininas e de substâncias semelhantes à histamina, que levam à vasodilatação.

A redução da viscosidade do sangue, também decorrente do aquecimento, pode contribuir para o aumento do fluxo sanguíneo.

De acordo com DYSON ${ }^{\bullet}$ apud KITCHEN \& PARTRIDGE (1990), efeitos térmicos podem ser produzidos sob doses terapêuticas de 0,5 - 3,0 $\mathrm{W} / \mathrm{cm}^{2}$ e efeitos não-térmicos, entre 0,1 e $0,2 \mathrm{~W} / \mathrm{cm}^{2}$.

\section{Efeitos não-térmicos}

Os efeitos não-térmicos das ondas ultra-sonoras incluem a cavitação, correntes acústicas e ondas estacionárias.

\section{Cavitação}

É a formação de pequenas bolhas gasosas nos tecidos como resultado da vibração do ultra-som. Irradiar ultra-som em líquidos leva à formação de bolhas de $10^{-6} \mu \mathrm{m}$ de diâmetro, que resultam em dois tipos de cavitação: estável ou transitória. A cavitação estável ocorre quando bolhas oscilam de um lado para outro dentro das ondas de pressão do ultra-som, mas permanecem intactas. Quando o volume da bolha se altera, ela colapsa (implode), causando aumento na temperatura e na pressão local, caracterizando a cavitação transitória. A cavitação estável, associada com as correntes acústicas, é considerada de valor terapêutico, mas a cavitação

\footnotetext{
- DYSON, M (1990). Oral communication; The 4th International Biotherapy Laser Association Seminar on Laser Biomodulation, Londres apud KITCHEN, S.; PARTRIDGE, C. J. (1990). A review of therapeutic ultrasound, v.76, n.10, p.593-600.
} 
transitória, que provavelmente só ocorre com altas intensidades, pode causar danos teciduais. A cavitação pode ser facilmente demonstrada experimentalmente nos tecidos moles, onde seu comportamento não está ainda suficientemente esclarecido, mas sabe-se que não parece ser prejudicial (HAAR, 1987; LOW \& REED, 2001).

A cavitação estável resulta em microvibrações que produzem um fluxo líquido localizado ao redor das bolhas e, conseqüentemente, adjacente às células (KITCHEN \& PARTRIDGE, 1990).

\section{Correntes acústicas}

É um fluxo circulatório devido ao torque de irradiação. Além disso, como já foi discutido no mecanismo da cavitação, ocorre um movimento localizado e unidirecional de líquido em torno da bolha que está vibrando. Esses movimentos muito pequenos de líquido também ocorrem em torno das células, caracterizando o efeito chamado microfluxo (LOW \& REED, 2001).

\section{Ondas estacionárias}

Como já foi descrito anteriormente, as ondas estacionárias ocorrem como resultado da sobreposição das ondas incidentes e refletidas. Visto que a onda estacionária consiste em duas ondas superpostas, além de um componente de deslocamento, as intensidades e pressões de pico são mais elevadas que as da onda incidente normal. Células fixas, como as células endoteliais que revestem os vasos sanguíneos, podem ser lesadas, levando à formação de trombos (KITCHEN \& BAZIN, 1998; LOW \& REED, 2001). As ondas estacionárias são evitadas com a simples movimentação contínua do cabeçote ultra-sônico durante o tratamento (HAAR, 1987).

O calor e a cavitação são os mecanismos que causam a maioria dos efeitos terapêuticos do ultra-som (HAAR, 1987). Provavelmente, são também os dois mecanismos que explicam a facilitação da penetração transcutânea de medicamentos na pele tratada com esse recurso. 


\subsection{Sonoforese ou fonoforese}

Sonoforese ou fonoforese é a utilização da energia ultra-sônica com a finalidade de facilitar a penetração transcutânea de drogas de uso tópico e tal procedimento tem demonstrado ser eficaz na penetração de corticoesteróides (BYL et al., 1993), vasodilatadores (McELNAY et al., 1993), proteínas (MITRAGOTRI et al., 1995) e indometacina (ASANO et al., 1997).

Em muitos casos, a sonoforese apresenta vantagens sobre outros métodos de administração de drogas, como a oral, a intramuscular e a endovenosa. Comparada à administração oral de medicamentos, a sonoforese evita a agressão ao trato gastrintestinal, cujos efeitos colaterais associados são bem conhecidos. Comparada æ̀ injeções intramuscular e endovenosa, a sonoforese elimina completamente o medo e a dor associados a estes métodos. Por outro lado, a sonoforese tem a barreira da baixa permeabilidade da pele em razão de sua camada mais externa, a camada córnea, o que é uma desvantagem do método (WU et al., 1998).

A indução à absorção transcutânea de drogas pela sonoforese baseia-se na perturbação tecidual, ou seja, na mudança da estrutura das camadas cutâneas (LOW \& REED, 2001). Pode ser aplicada com um gel ou creme medicamentoso como meio de acoplamento do cabeçote ultra-sônico ou com o pré-tratamento da pele com o ultra-som, seguido da aplicação do medicamento tópico.

Quando a aplicação for com o gel ou creme medicamentoso como meio de acoplamento, deve-se ter certeza de que esse é um bom transmissor ultra-sonoro, caso contrário, parece pouco provável que o tratamento possa funcionar efetivamente (LOW \& REED, 2001).

Esse fato foi considerado por BENSON \& McELNAY (1994), que pesquisaram as características de transmissão ultra-sonora de um grande número de produtos diferentes e encontraram muitas variações, inclusive demonstrando que alguns deles eram maus transmissores. A transmissividade de cada formulação é dada pela porcentagem da 
transmissão do produto em relação à da água deionizada, cujos valores podem ser observados na Tabela 1.

TABELA 1 - Transmissividade de formulações tópicas em relação àágua deionizada.

\begin{tabular}{|c|c|c|c|c|c|}
\hline \multirow[t]{2}{*}{ Product } & \multirow[t]{2}{*}{ Active ingredient } & \multirow{2}{*}{$\begin{array}{l}\text { Uitrasound } \\
\text { output: intensity } \\
\text { (watts: W/cm²) }\end{array}$} & \multicolumn{3}{|c|}{ 96 Transmission relative to water ( $\pm S D$ ) } \\
\hline & & & $0.65 \mathrm{MHz}$ & $1.5 \mathrm{MHz}$ & $3.0 \mathrm{MHz}$ \\
\hline Feldene gel & $0.5 \%$ piroxicam & $\begin{array}{l}1.5: 0.3 \\
5.0: 1.0\end{array}$ & $\begin{array}{l}74.67 \pm 5.33 \\
52.85 \pm 2.44\end{array}$ & $\begin{array}{r}108.00 \pm 2.67 \\
100.80 \pm 3.40\end{array}$ & $\begin{array}{l}108.00 \pm 5.33 \\
118.40 \pm 7.40\end{array}$ \\
\hline Ibugel & $5 \%$ lbuproten & $\begin{array}{l}1.5: 0.3 \\
5.0: 1.0\end{array}$ & $\begin{array}{l}56.00 \pm 3.30 \\
48.40 \pm 1.60\end{array}$ & $\begin{aligned} 94.67 & \pm 2.67 \\
101.99 & \pm 0.79\end{aligned}$ & $\begin{array}{l}113.33 \pm 4.67 \\
116.06 \pm 3.82\end{array}$ \\
\hline Oruvail gel & $2.5 \%$ ketoprofen & $\begin{array}{l}1.5: 0.3 \\
5.0: 1.0\end{array}$ & $\begin{array}{l}110.67 \pm 0.33 \\
111.55 \pm 0.00\end{array}$ & $\begin{aligned} 98.67 & \pm 2.67 \\
105.93 & \pm 1.78\end{aligned}$ & $\begin{array}{l}108.00=5.33 \\
122.22 \pm 2.98\end{array}$ \\
\hline Proflex cream & $5 \%$ ibuprofen & $\begin{array}{l}1.5: 0.3 \\
5.0: 1.0\end{array}$ & $\begin{array}{l}60.00 \pm 0.00 \\
49.00 \pm 5.78\end{array}$ & $\begin{array}{l}89.33 \pm 3.33 \\
89.56 \pm 1.00\end{array}$ & $\begin{array}{l}70.67 \pm 7.33 \\
85.34 \pm 3.95\end{array}$ \\
\hline Traxam gel & $3 \%$ felbinac & $\begin{array}{l}1.5: 0.3 \\
5.0: 1.0\end{array}$ & $\begin{array}{l}61.33 \pm 2.67 \\
94.30 \pm 7.98\end{array}$ & $\begin{aligned} 93.33 & \pm 0.00 \\
105.45 & \pm 1.56\end{aligned}$ & $\begin{array}{l}120.00 \pm 8.00 \\
112.06 \pm 2.92\end{array}$ \\
\hline Voltarol Emulgel & $\begin{array}{l}1.16 \% \text { diclofenac } \\
\text { ethylammonium salt } \\
\text { (equivalent to } 1 \% \\
\text { diclofenac sodium) }\end{array}$ & $\begin{array}{l}1.5: 0.3 \\
5.0: 1.0\end{array}$ & $\begin{array}{r}106.67 \pm 0.00 \\
81.75 \pm 1.59\end{array}$ & $\begin{aligned} 98.67 & \pm 2.67 \\
105.51 & \pm 0.98\end{aligned}$ & $\begin{array}{r}92.00 \pm 8.67 \\
110.08 \pm 2.52\end{array}$ \\
\hline
\end{tabular}

Fonte: BENSON \& McELNAY (1994).

A transmissividade é uma propriedade intrínseca dos géis, mas aumenta com o aumento da energia ultra-sônica, particularmente com a freqüência. Todavia, freqüências altas de ultra-som podem causar quebra nas cadeias de polímeros responsáveis pela viscosidade dos agentes utilizados nas formulações tópicas, fluidificando-os e reduzindo sua capacidade de atenuar a energia ultra-sônica (BENSON \& McELNAY, 1994). Entretanto, esse fenômeno ainda não está totalmente esclarecido, necessitando de novas investigações.

BYL et al. (1993) mensuraram indiretamente a difusão de corticoesteróides através da pele de porcos, pela medida da deposição de colágeno, estimada pelos níveis de hidroxiprolina, e pela observação das mudanças na atividade celular, avaliada pelos níveis de DNA. Para isso, implantaram tubos de politetrafluroetileno no tecido subcutâneo dos animais 
e realizaram uma única aplicação de dexametasona ou de hidrocortisona. Em um grupo, a aplicação do medicamento foi através da sonoforese (US contínuo, $1,5 \mathrm{~W} / \mathrm{cm}^{2}, 1 \mathrm{MHz}, 5$ minutos), com a droga incorporada ao gel comum de acoplamento. No outro, a droga foi aplicada através da injeção de uma ou outra das drogas. Um grupo controle recebeu ultra-som placebo com gel comum, enquanto que outro recebeu ultra-som placebo com gel adicionado de dexametasona ou hidrocortisona. Os autores encontraram redução significativa na deposição de colágeno no grupo tratado com sonoforese e dexametasona e no grupo que recebeu injeção de dexametasona, quando comparados com os grupos controles. Não houve diferenças significativas nos níveis de hidroxiprolina entre os grupos controle e os grupos tratados com hidrocortisona. Também não houve diferenças significativas nos níveis de atividade celular. Considerando a metodologia utilizada, os autores demonstram efeito indutor da sonoforese à absorção transcutânea de dexametasona.

McELNAY et al. (1993) analisaram a resposta vasodilatadora ao metilnicotinato, aplicado na pele do antebraço de voluntários pré-tratada com ultra-som (contínuo, $1,0 \mathrm{~W} / \mathrm{cm}^{2}, 3 \mathrm{MHz}$ ) e ultra-som placebo por 5 minutos, utilizando gel de acoplamento comum. A vasodilatação foi quantificada através da medida do fluxo sanguíneo cutâneo por meio de um velocímetro Doppler a laser (LDV), a intervalos de 1 minuto por 1 hora ou até que o fluxo sanguíneo retornasse aos valores prévios ao tratamento. Os resultados obtidos demonstraram que o pré-tratamento da pele com o ultra-som induziu o aumento significativo da absorção transcutânea do metil-nicotinato. Os autores sugeriram que o mecanismo de ação pelo qual o ultra-som facilita a penetração transcutânea de drogas é a alteração estrutural da pele, desordenando as cadeias lipídicas nos canais intercelulares de sua camada córnea. Apesar dos autores terem chegado a essa conclusão, eles não realizaram mensuração do fluxo sanguíneo após a aplicação do ultra-som e do placebo, antes da aplicação do vasodilatador, para descartar a possibilidade de as alterações do fluxo sanguíneo terem sido causadas por esses agentes. 
ROBINSON \& BUONO (1994) determinaram o efeito do ultra-som terapêutico (contínuo, $1 \mathrm{MHz}, 1,5 \mathrm{~W} / \mathrm{cm}^{2}, 5$ minutos) no fluxo sanguíneo total do antebraço, através de pletismografia de oclusão venosa, e no fluxo da pele, através de fuxometria pelo Doppler a laser. A diferença entre essas duas mensurações forneceu o fluxo sanguíneo muscular. $O$ ultra-som foi aplicado na face ventral do antebraço de 20 voluntários saudáveis, enquanto que o antebraço contra-lateral serviu de controle, pois recebeu tratamento placebo com o equipamento de ultra-som desligado. As mensurações foram realizadas antes e depois da aplicação do tratamento. Nenhuma diferença significativa foi encontrada entre os valores de fluxo sanguíneo nos antebraços efetivamente irradiados e nos controles, tanto na pele quanto no músculo, até 30 minutos após o tratamento. Uma limitação desse estudo foi a não monitoração do fluxo sanguíneo durante a aplicação do tratamento, quando alterações poderiam ter ocorrido.

MITRAGOTRI et al. (1995) investigaram a penetração transcutânea de proteínas - insulina, interferon e eritropoetina - induzida pelo ultra-som de baixa intensidade. Devido ao seu alto peso molecular, essas proteínas são virtualmente incapazes de penetrar na pele. Inicialmente, os autores mensuraram a permeabilidade da pele a essas proteínas in vitro, utilizando epiderme de cadáveres para separar um compartimento doador e um receptor. O ultra-som (pulsado $100 \mathrm{~ms}$, intensidade de 12,5 a $225 \mathrm{~mW} / \mathrm{cm}^{2}$, freqüência de $20 \mathrm{KHz}$, aplicações de 4 horas) foi mantido no compartimento doador, preenchido com uma solução da proteína, enquanto que a concentração das proteínas no compartimento receptor foi mensurada de hora em hora por meio de radioimunoensaio (RIA) e pelo método imunoenzimático (ELISA). Os autores constataram que o ultra-som induziu a significativa penetração transcutânea das três proteínas, já na primeira hora do tratamento.

Em seguida, os autores analisaram dois aspectos importantes da sonoforese, que são a reversibilidade da facilitação do transporte transdérmico, ou seja, a recuperação das propriedades de barreira da pele após a remoção do ultra-som, e a eficácia no controle da penetração transcutânea 
variando o parâmetro intensidade. Observaram que a aplicação do ultra-som não causou qualquer perda permanente das propriedades de barreira da pele, pois 0 transporte transdérmico de insulina foi estatisticamente insignificante 3 horas após o ultra-som ter sido desligado. Quanto ao segundo aspecto, os autores realizaram um estudo in vivo, utilizando um modelo de penetração da insulina na pele de ratos induzida pelo ultra-som, com variações dos parâmetros intensidade e tempo de tratamento, e comparando os resultados com os da injeção subcutânea da insulina, através da medida da glicemia. Os autores constataram que a dose de insulina absorvida é dependente da intensidade de aplicação do ultra-som, tendo variado de 0 a 1 unidade numa área de $3 \mathrm{~cm}^{2}$. Por exemplo, dez minutos de aplicação de ultra-som na intensidade de $225 \mathrm{~mW} / \mathrm{cm}^{2}$ induziram a penetração de aproximadamente $100 \mathrm{mU}$ de insulina, numa área de $3 \mathrm{~cm}^{2}$.

Para finalizar, os autores realizaram estudos histológicos na pele dos ratos que receberam ultra-som nas intensidades de 12,5 a $225 \mathrm{~mW} / \mathrm{cm}^{2}$ e observaram a ausência de qualquer dano na pele e nas camadas musculares adjacentes expostas ao ultra-som.

ASANO et al. (1997) investigaram os efeitos do ultra-som (1 MHz, contínuo e pulsado, $0,5-2,5 \mathrm{~W} / \mathrm{cm}^{2}, \quad 10-19$ minutos) na absorção transcutânea de indometacina, um antiinflamatório não-hormonal, em ratos. Para isso, os autores aplicaram uma pomada contendo $1 \%$ de indometacina, cobriram com um filme plástico e aplicaram ultra-som com gel comum sobre o filme. Um grupo controle foi tratado com procedimento placebo, sem a aplicação do transdutor utra-sônico. Amostras de sangue foram coletadas dos ratos em intervalos de 1 hora até 4 horas após o tratamento e foram analisadas através de cromatografia líquida de alta eficiência (HPLC). Houve aumento significativo na penetração transcutânea de indometacina com 0 ultra-som pulsado nos seguintes conjuntos de parâmetros: A) pulsado 1:2, $1,0 \mathrm{~W} / \mathrm{cm}^{2}, 15$ minutos; B) pulsado $1: 2,2,0 \mathrm{~W} / \mathrm{cm}^{2}, 10$ minutos; e C) pulsado 1:4, 2,5 W/cm ${ }^{2}, 10$ minutos. Nos conjuntos de parâmetros $B$ e $C$, houve ainda aumento da temperatura hipodérmica proporcional à intensidade do ultra-som, conforme medidas feitas com um termistor. O exame histológico 
da pele mostrou que com o conjunto de parâmetros $A$ não houve alterações na epiderme, derme e hipoderme, mas com o conjunto B houve atrofia e necrose da epiderme, e com o conjunto $\mathrm{C}$, somente atrofia da epiderme.

Com o ultra-som contínuo, também houve aumento significativo na penetração transcutânea de indometacina nos seguintes conjuntos de parâmetros: A) $0,5 \mathrm{~W} / \mathrm{cm}^{2}, 10$ minutos; e B) $1,0 \mathrm{~W} / \mathrm{cm}^{2}, 10$ minutos. $A$ absorção da indometacina foi maior com o conjunto $B$, mas houve atrofia da epiderme. Com o conjunto $A$ não houve aumento da temperatura, nem qualquer dano tecidual.

Estudos clínicos em pacientes também têm sido realizados para investigar a eficácia da sonoforese de medicamentos, quando comparada à utilização do ultra-som com gel comum.

EL-HADIDI \& EL-GARF (1991) realizaram um estudo duplo-cego comparando a utilização de Voltaren Emulge ${ }^{\circledR}$ com o gel de acoplamento comum, durante sessões de ultra-som (contínuo, 1,0 W/cm², 10 minutos) no tratamento de condições dolorosas traumáticas e reumáticas localizadas, em 120 pacientes com dor de grau moderado a grave. Os pacientes foram separados aleatoriamente para que o grupo de tratamento com Voltaren Emulge ${ }^{\circledR}$ e o grupo de tratamento com gel comum recebessem sessões de ultra-som três vezes por semana durante quatro semanas. Eles foram avaliados quanto à sensibilidade à pressão, dor ao movimento passivo, dor em repouso e dor ao movimento ativo. Uma melhora estatisticamente significativa foi obtida em ambos os grupos de tratamento, ao final da primeira semana, na maioria dos critérios de avaliação. Durante todo o período do estudo, os resultados da avaliação também foram significativamente melhores no grupo com o antiinflamatório. $\mathrm{O}$ tratamento foi interrompido prematuramente em $60 \%$ dos pacientes tratados com Voltaren Emulge ${ }^{\circledR}$, devido à cura completa do processo, contra $15 \%$ no grupo tratado com o gel comum. Os resultados desse estudo sugerem fortemente que a utilização de Voltaren Emulge $^{\circledR}$ como meio de acoplamento para o tratamento com o ultra-som é mais eficaz que o gel comum. 
KLAIMAN et al. (1998) examinaram a eficácia da sonoforese comparada ao tratamento isolado com o ultra-som terapêutico, através de um estudo duplo-cego em 49 indivíduos com diagnósticos de epicondilite, tendinite e tenossinovite ${ }^{\bullet}$. Os indivíduos foram separados em pares, de acordo com suas patologias músculo-esqueléticas e cada paciente de cada par foi aleatoriamente designado ao grupo que recebeu o tratamento com o ultrasom (contínuo, $1 \mathrm{MHz}, 1,5 \mathrm{~W} / \mathrm{cm}^{2}$, 8 minutos), com gel adicionado de $0,05 \%$ de fluocinonide, ou ao grupo que recebeu tratamento idêntico exceto pela ausência do esteróide. Os pacientes receberam tratamento três vezes por semana por três semanas consecutivas e foram avaliados quanto ao nível da dor, utilizando uma escala visual análoga de dor e algometria de pressão. Ao final da terceira semana, ambos os grupos demonstraram redução significativa no nível da dor e aumento da tolerância à pressão, mas as diferenças entre os grupos não foram significantes. Esses resultados sugerem que o ultra-som pode ser aplicado para reduzir a dor e a tolerância à pressão nas patologias músculo-esqueléticas selecionadas, sem que a adição do esteróide fluocinonide interfira na eficácia do tratamento.

\subsection{O ultra-som e a pele}

Embora o ultra-som demonstre facilitar a penetração transcutânea de uma variedade de drogas, o mecanismo desse fenômeno não está esclarecido.

O calor e a cavitação são os mecanismos que causam a maioria dos efeitos terapêuticos do ultra-som (HAAR, 1987) e provavelmente são, também, os envolvidos na facilitação da penetração de medicamentos através da pele.

A camada mais externa da pele humana (camada córnea) tem aproximadamente $15 \mu \mathrm{m}$ de espessura e é constituída de queratinócitos, que são células achatadas, mortas e sem núcleo, rodeadas por camadas

\footnotetext{
- Epicondilite lateral, tendinite bicipital, tendinite do supraespinhoso, tenossinovite de DeQuervain, tendinite de Aquiles, tendinite patelar e fascite plantar.
} 
lipídicas (MITRAGOTRI et al., 1995; WU et al. 1998). O citoplasma dessas células apresenta-se repleto de uma escleroproteína filamentosa e birrefringente, a queratina, rica em ligações dissulfeto (JUNQUEIRA \& CARNEIRO, 1999). A baixa permeabilidade da pele é atribuída à estrutura altamente ordenada dos queratinócitos e suas camadas lipídicas, presentes na camada córnea (MITRAGOTRI et al., 1995; WU et al. 1998).

FRENKEL et al. (1999) expuseram a pele de peixes ao ultra-som terapêutico (contínuo, $1 \mathrm{MHz}, 0,5-2,2 \mathrm{~W} / \mathrm{cm}^{2}$ ) e analisaram biópsias da pele, através de microscopia eletrônica. Primeiramente, os autores determinaram os efeitos do ultra-som na água, sem o peixe. Foram mensurados o pH, a temperatura e a concentração de oxigênio antes e depois da aplicação do ultra-som na água. Nenhuma diferença significativa foi encontrada nesses três parâmetros, indicando que o ultra-som não alterou as propriedades físicas da água. O peixe foi fixado dentro de um tanque plástico e o transdutor ultra-sônico foi posicionado a $15 \mathrm{~cm}$ dele. A elevação da temperatura na pele do peixe também foi mensurada por um termistor implantado entre a derme e o músculo subjacente. O termistor foi conectado a um computador que permitiu visualizar os dados em tempo real. Um segundo termistor foi utilizado para monitorar a temperatura da água durante o experimento e não foi detectada qualquer alteração. A temperatura da pele do peixe aumentou em média $0,3{ }^{\circ} \mathrm{C}$, em média após 15 segundos da presença da energia ultra-sônica. Imediatamente após a exposição ao ultrasom, foi realizada biópsia da pele, que foi analisada por microscopia eletrônica. Não foi observado nenhum dano estrutural com a intensidade de $0,5 \mathrm{~W} / \mathrm{cm}^{2}$, com 30, 60 e 90 segundos de aplicação. Aumentando a intensidade para $0,75 \mathrm{~W} / \mathrm{cm}^{2}$, não foi observado dano estrutural com 30 e 60 segundos de aplicação, mas com 90 segundos foram observados os primeiros sinais de danos, sob a forma de pequenas rupturas $(0,01-0,1 \mu \mathrm{m})$ na superfície das membranas celulares. Um grau muito maior de dano celular foi observado com a intensidade de $1,0 \mathrm{~W} / \mathrm{cm}^{2}$, já com 5 segundos de aplicação do ultra-som, com a presença de grandes rupturas, maiores do que $1 \mu \mathrm{m}$ de extensão, na superfície de algumas células. Essas células 
sofreram necrose, permitindo fácil distinção com as células viáveis ao exame microscópico. Ainda com $1,0 \mathrm{~W} / \mathrm{cm}^{2}$, a partir de 20 segundos de aplicação do ultra-som, foram observados danos nas duas primeiras camadas de células, mais acentuados na camada mais externa. Também foram observadas falhas na superfície, com dispersão dos componentes celulares. Com 30 segundos de aplicação do ultra-som, todas as células da camada externa estavam necróticas. Aumentando para 60 e 90 segundos, os resultados foram progressivos no que diz respeito ao dano tecidual, propagando-se até a sexta camada de células. Com esses dados, os autores puderam concluir que a cavitação é dependente da intensidade e do tempo de aplicação do ultra-som e que intensidades altas provocam a necrose de células.

Esses mesmos autores repetiram o experimento um ano mais tarde (FRENKEL et al., 2000), porém utilizando uma fonte de ultra-som de $3 \mathrm{MHz}$ de freqüência, aplicado em diferentes ângulos. Expuseram peixes ao ultrasom contínuo, com intensidades de 0,5 a 2,2 W/cm ${ }^{2}$ e analisaram biópsias da pele pela microscopia eletrônica. Não houve qualquer alteração na água nos parâmetros temperatura, $\mathrm{pH}$ e concentração de oxigênio. A elevação da temperatura na pele do peixe foi novamente de $0,3{ }^{\circ} \mathrm{C}$ e foi alcançada, em média, após 15 a 20 segundos da presença da energia ultra-sônica. Desta vez, o fenômeno da cavitação não foi detectado mesmo na máxima intensidade investigada. As camadas mais externas da epiderme apresentaram-se normais quando comparadas com o controle e os primeiros sinais de efeitos biológicos, à aplicação perpendicular do ultra-som, foram observados após 90 segundos com intensidade de $1,7 \mathrm{~W} / \mathrm{cm}^{2}$, quando os espaços intercelulares apresentaram-se alargados, com falhas de 0,3 $\mu \mathrm{m}$ de largura, estendendo-se horizontalmente entre os desmossomos de duas camadas adjacentes, com alguns desmossomos totalmente dissociados. Algumas falhas e dissociações de desmossomos no sentido vertical também foram observadas, porém menos pronunciadas. Um acentuado alargamento dos espaços intercelulares foi observado quando a intensidade foi aumentada para $2,2 \mathrm{~W} / \mathrm{cm}^{2}$, com aplicação perpendicular por 30 segundos. 
Nesse caso, as falhas provocadas foram de 1 a $2 \mu \mathrm{m}$ de largura, com algumas alcançando até $3 \mu \mathrm{m}$. Falhas entre as duas camadas mais externas surgiram com 60 segundos de aplicação do ultra-som, enquanto que com 90 segundos as separações foram maiores entre as duas camadas mais externas, algumas células estando completamente desatadas das camadas mais profundas, permanecendo conectadas apenas pela superfície das células vizinhas. Quando o ultra-som foi aplicado com o cabeçote inclinado a $45^{\circ}$ (2,2 W/cm², 90 segundos), o alargamento dos espaços intercelulares foi observado tanto no plano horizontal como no vertical, inclusive mais profundamente, atingindo até a quarta ou quinta camada de células. Apesar desses achados, nenhuma modificação foi observada na superfície das células, que permaneceram íntegras, em comparação com as perfurações na membrana celular e necrose celulares observadas no estudo anterior com ultra-som de $1 \mathrm{MHz}$ de freqüência, a partir da intensidade de 0,75 $\mathrm{W} / \mathrm{cm}^{2}$ e duração de 90 segundos. Com os resultados obtidos desses dois trabalhos, os autores sugerem que o alargamento do espaço intercelular não é resultante nem do efeito térmico nem da cavitação do ultra-som, mas sim um novo fenômeno, até então não descrito na literatura e com o mecanismo de ação desconhecido.

WU et al. (1998) observaram alterações estruturais geradas pelo ultrasom $\left(168 \mathrm{KHz}, 1,2 \mathrm{~W} / \mathrm{cm}^{2}\right)$ na camada córnea humana de cadáveres, através da microscopia de fluorescência. A amostra de pele foi colocada dentro de um tanque com água e o transdutor ultra-sônico foi posicionado a $15 \mathrm{~cm}$ da amostra. As imagens obtidas antes da exposição ao ultra-som evidenciam a estrutura hexagonal ordenada dos queratinócitos, enquanto que, após 15 minutos de ultra-som, essa estrutura ficou distorcida e desorganizada. As imagens mostram regiões escuras de aproximadamente $20 \mu \mathrm{m}$, correspondentes à falhas geradas na camada córnea. Conforme já discutido anteriormente, acredita-se que a estrutura altamente ordenada das camadas lipídicas entre os queratinócitos da camada córnea seja a responsável pela impermeabilidade da pele às drogas. Esse experimento mostrou que o ultra-som induziu alterações no arranjo dos queratinócitos da 
camada córnea da pele e criou defeitos destituídos de moléculas lipídicas, descritas como sendo bolsas de ar. As dimensões desses defeitos foram da ordem de $20 \mu \mathrm{m}$, relevantes para aumentar a permeabilidade da pele e permitir a passagem de moléculas de drogas através da camada córnea, reforçando a hipótese da cavitação ser a possível explicação para o sucesso da sonoforese.

\subsection{Objetivo}

Foi o objetivo do presente estudo testar a hipótese de que a aplicação do ultra-som terapêutico com baixa freqüência $(1 \mathrm{MHz})$ e intensidade $(0,5$ $\mathrm{W} / \mathrm{cm}^{2}$ ) e curta duração (5 minutos) de cada lado induz um aumento na absorção transcutânea de um medicamento antiinflamatório conhecido (diclofenaco sódico na forma de gel) pela pele de humanos. 


\section{MATERIAL E MÉTODOS}

\section{$2.1 \quad$ Voluntários}

Participaram do estudo 14 voluntários saudáveis, sendo dez mulheres e quatro homens, estudantes universitários, com idade média de 26,4 anos (variação: 19-50), peso médio de $62 \mathrm{Kg}$ (variação: 50-80) e altura média de 1,7 metro (variação: 1,6-1,9).

Para minimizar os efeitos das propriedades individuais da pele, os mesmos voluntários constituíram tanto o grupo de tratamento (Grupo $A$, com o equipamento de ultra-som ligado), como o grupo-controle (Grupo B, com o equipamento de ultra-som desligado), sendo que cada indivíduo foi seu próprio controle, em aplicações idênticas com intervalo de um mês.

Todos os voluntários foram devidamente cientificados da natureza e propósitos do estudo, assinando um termo de informação e consentimento (ANEXO A). Todos passaram por um cuidadoso exame de inspeção da pele, no local elegido para a aplicação do tratamento, e por um interrogatório sobre o estado geral de saúde (ANEXO B), tendo sido constatado que estavam livres de problemas cardíacos, hepáticos, renais, pulmonares, gastrintestinais, neurológicos, hematológicos e doenças dermatológicas além de não estarem ingerindo nenhum tipo de medicamento. Foram também critérios de seleção não serem fumantes, não ter ingerido bebidas alcoólicas por uma semana, não ter hipersensibilidade ou contra-indicação ao uso do diclofenaco ou outro antiinflamatório e, no caso das mulheres, afastada a possibilidade de gravidez. Foram adotados como critérios de exclusão a presença de apenas uma resposta afirmativa a qualquer um dos itens do interrogatório ou a presença de solução de continuidade na pele.

O estudo foi devidamente aprovado pelo Comitê de Ética em Pesquisa do Hospital das Clínicas da Faculdade de Medicina de Ribeirão Preto da Universidade de São Paulo (ANEXO C).

Amostras de sangue $(3 \mathrm{ml})$ foram coletadas de veias do antebraço dos indivíduos imediatamente antes e 60, 120 e 180 minutos após a 
aplicação do procedimento e colocadas em tubos com $10 \mathrm{mg}$ do anticoagulante EDTA ${ }^{\circ}$ (FIGURA 4). O plasma permaneceu congelado a -20 ○C até a data da análise cromatográfica, que foi realizada no Instituto de Química de São Carlos da Universidade de São Paulo - USP.

\subsection{Equipamento de ultra-som}

O tratamento foi realizado com equipamento de ultra-som clínico de 1 $\mathrm{MHz}$ modelo PRO SEVEN 977-2000 produzido e gentilmente emprestado pela QUARK Produtos Médicos. Este equipamento é micro-processado e atende os requisitos da norma de segurança para equipamentos eletromédicos IEC 601 (norma geral) e IEC 601-2-5 (norma particular para equipamentos de ultra-som).

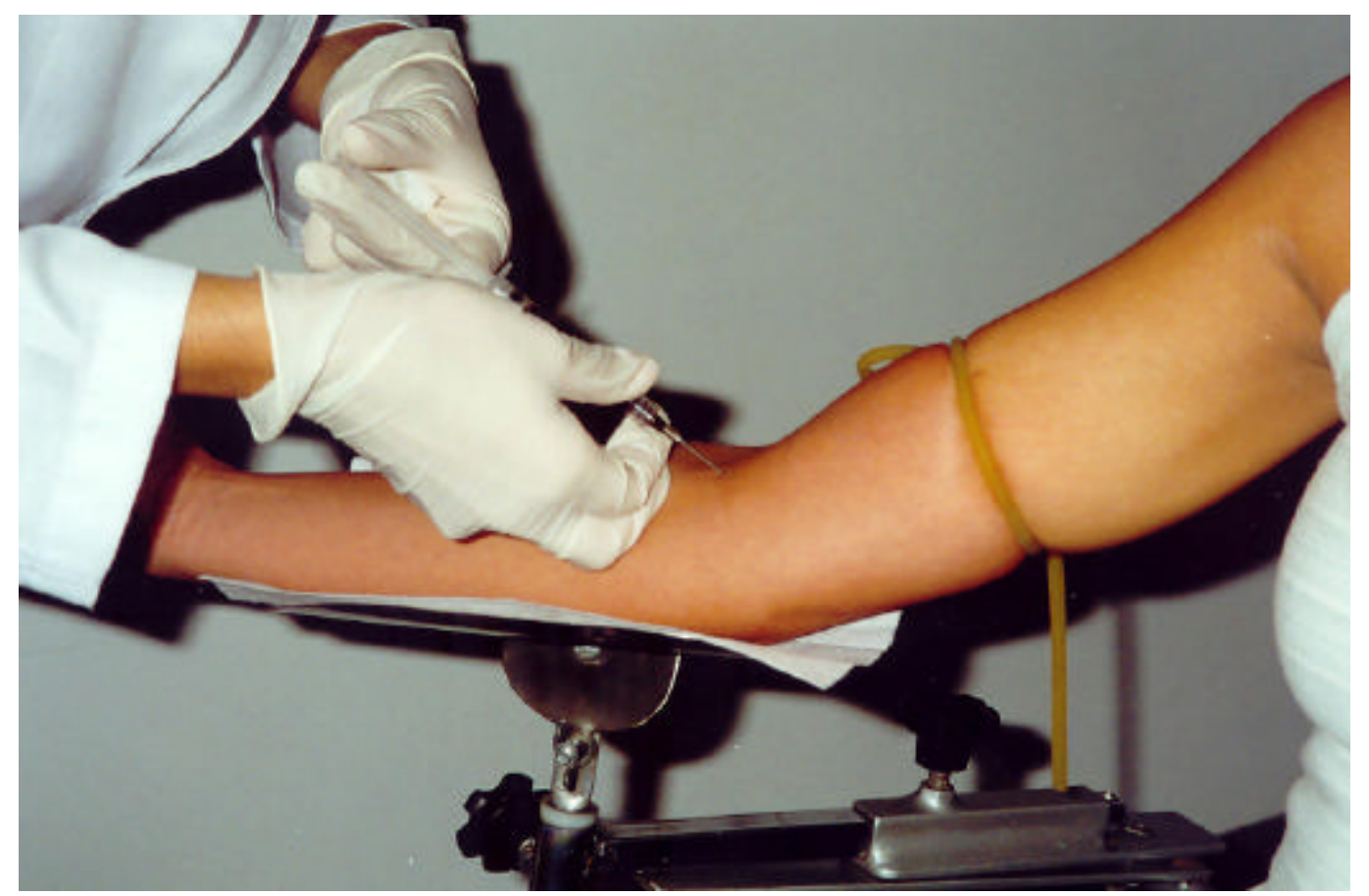

FIGURA 4. Extração do sangue de veias do antebraço dos voluntários.

• Laboratório de Análises Clínicas Eugênia Cabianca, Pirassununga, SP. 


\subsection{Especificações do gel medicamentoso}

O gel medicamentoso utilizado está comercialmente disponível em farmácias (Voltaren Emulge ${ }^{\circledR}$ ) e, conforme informações contidas na bula, contém $1 \mathrm{~g}$ do diclofenaco sódico a cada $100 \mathrm{~g}$ do gel, que tem como base uma emulsão oleosa em gel aquoso. Cada paciente recebeu $5 \mathrm{~g}$ do gel $(2,5$ g de cada lado da região dorsal), de modo que a massa total recebida foi equivalente a $0,05 \mathrm{~g}$ de diclofenaco sódico.

\subsection{Aplicação do ultra-som e do Voltaren Emulgel ${ }^{\circledR}$}

Inicialmente, foram demarcadas duas áreas de $225 \mathrm{~cm}^{2}(15 \times 15 \mathrm{~cm})$, uma de cada lado da região dorsal dos voluntários, para a aplicação do procedimento. Depois, os voluntários receberam o pré-tratamento da pele com uma única aplicação de ultra-som contínuo, de $1 \mathrm{MHz}$ de freqüência, $0,5 \mathrm{~W} / \mathrm{cm}^{2}$ de intensidade, por 5 minutos, nas duas áreas demarcadas, uma em seguida da outra, utilizando gel comum para acoplamento do cabeçote ultra-sônico (FIGURAS 5 e 6).

Em seguida ao pré-tratamento da pele com o ultra-som, luvas foram utilizadas para aplicar o Voltaren Emulge ${ }^{\circledR}$ nas duas áreas previamente irradiadas (FIGURAS 7 e 8), que foram mantidas descobertas até uma hora após a aplicação do gel, quando foi permitido aos voluntários o uso normal de suas roupas.

No Grupo A (grupo de tratamento), o procedimento foi realizado com o equipamento de ultra-som ligado e, portanto, efetivamente submetendo as áreas demarcadas à irradiação ultra-sônica. No Grupo B (grupo controle), composto pelos mesmos voluntários, mas submetidos ao procedimento um mês mais tarde, em média, o equipamento foi mantido desligado, de modo que ocorresse apenas o efeito placebo do ultra-som. 


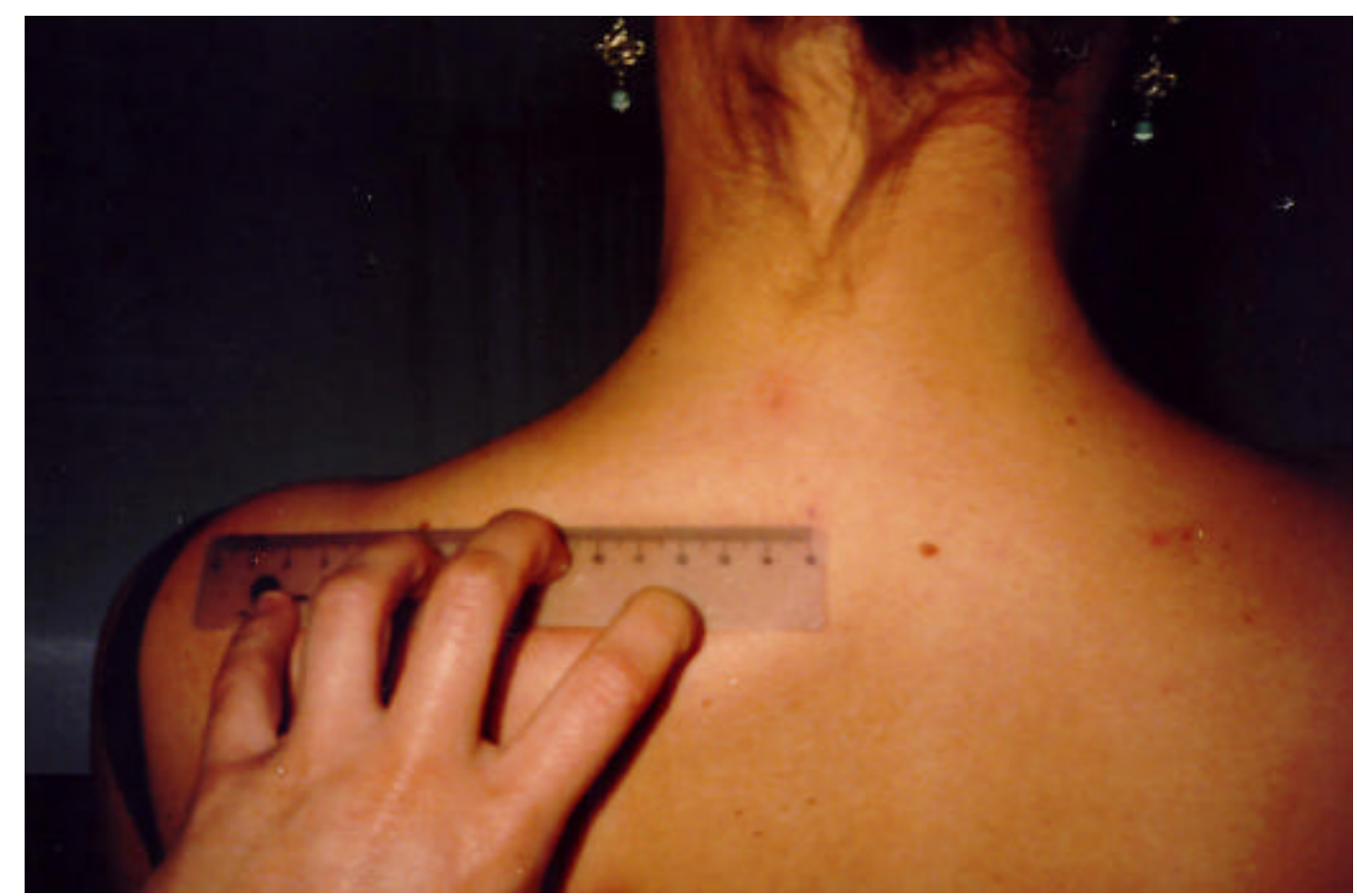

FIGURA 5. Determinação da área de aplicação de $225 \mathrm{~cm}^{2}(15 \times 15 \mathrm{~cm})$ de cada lado da região dorsal dos voluntários.

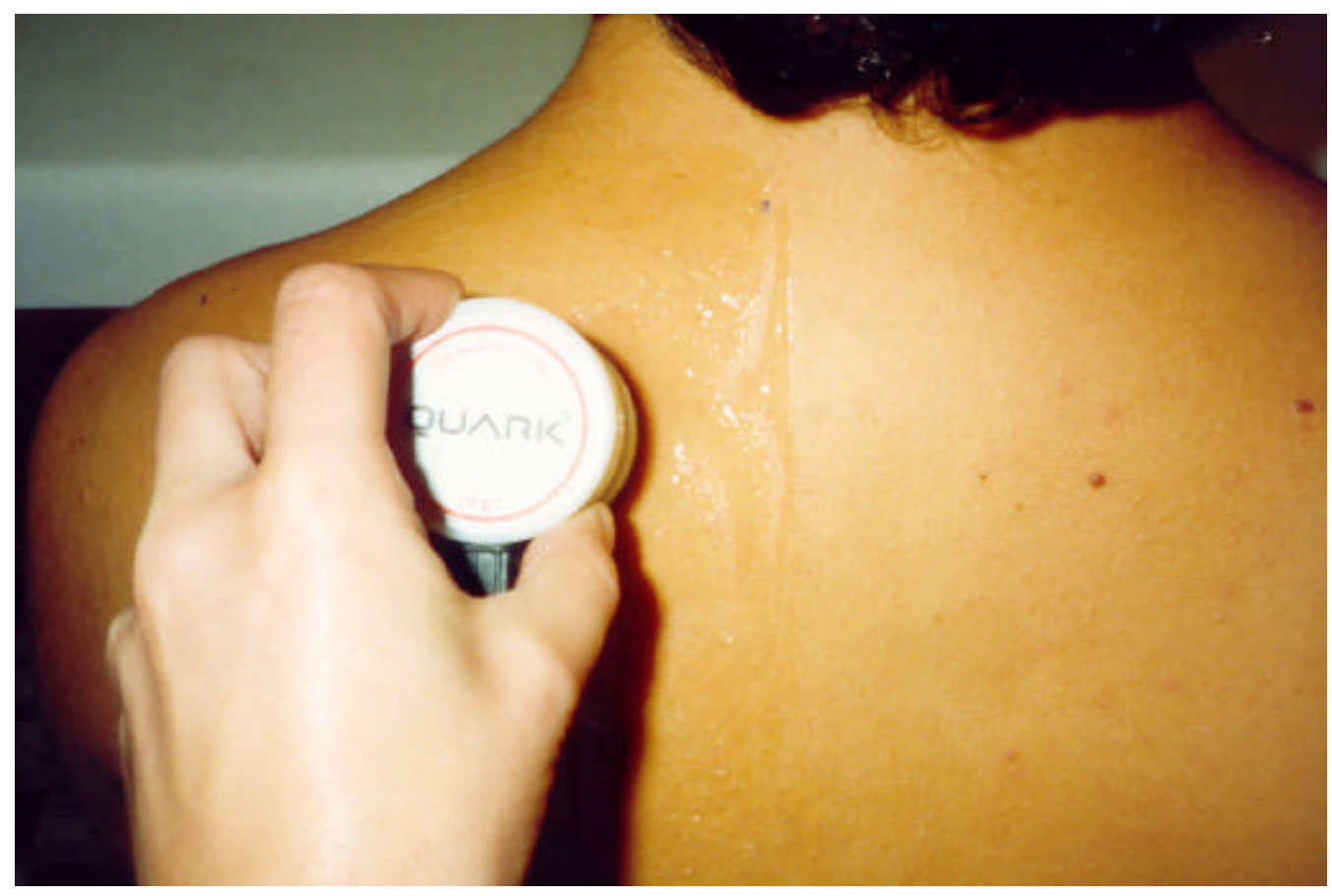

FIGURA 6. Aplicação do ultra-som nas áreas pré-determinadas utilizando gel comum para contato e acoplamento. 


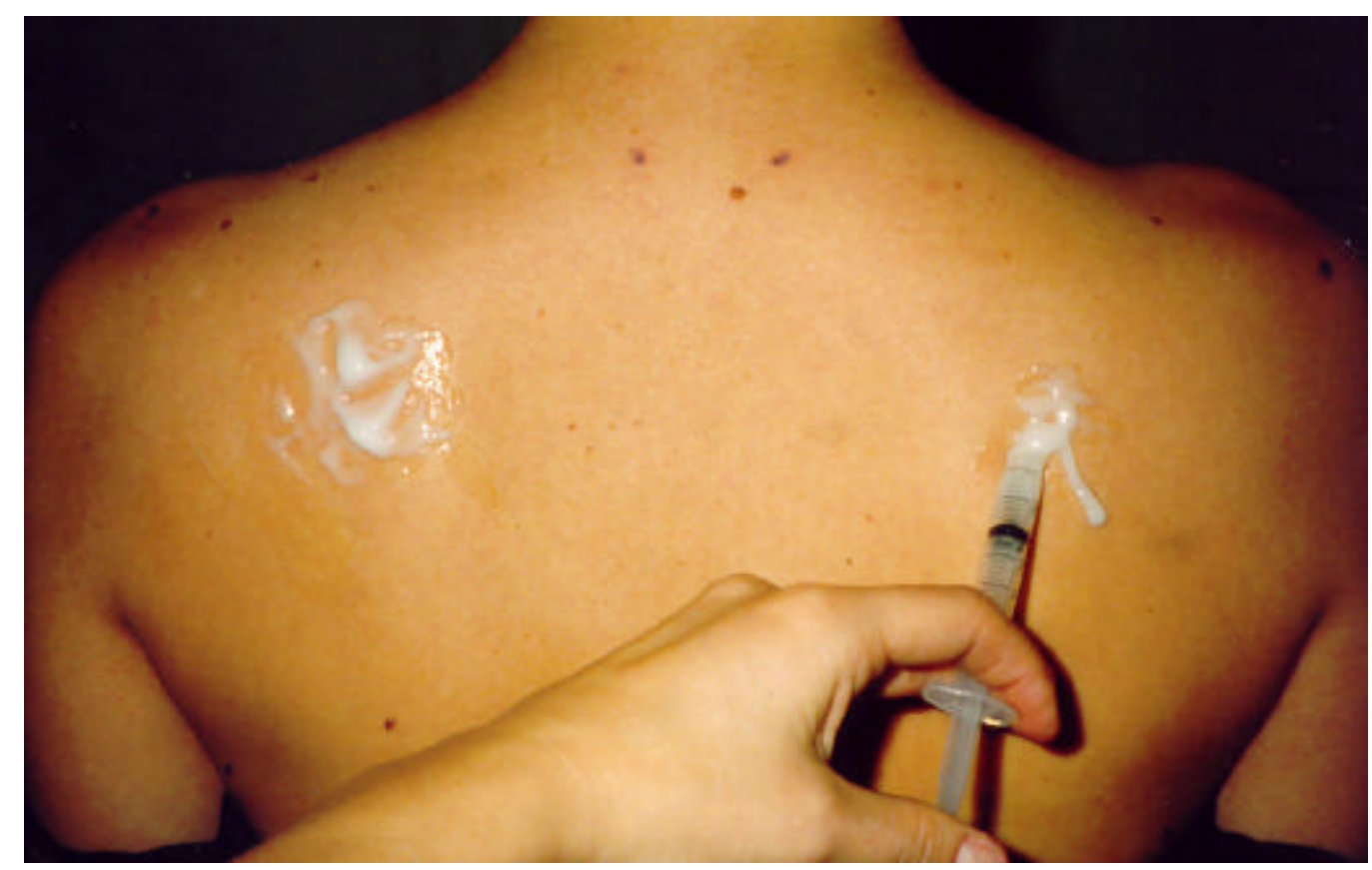

FIGURA 7. Mensuração de 2,5 g do gel de diclofenaco sódico a ser aplicado nas áreas pré-determinadas na região dorsal.

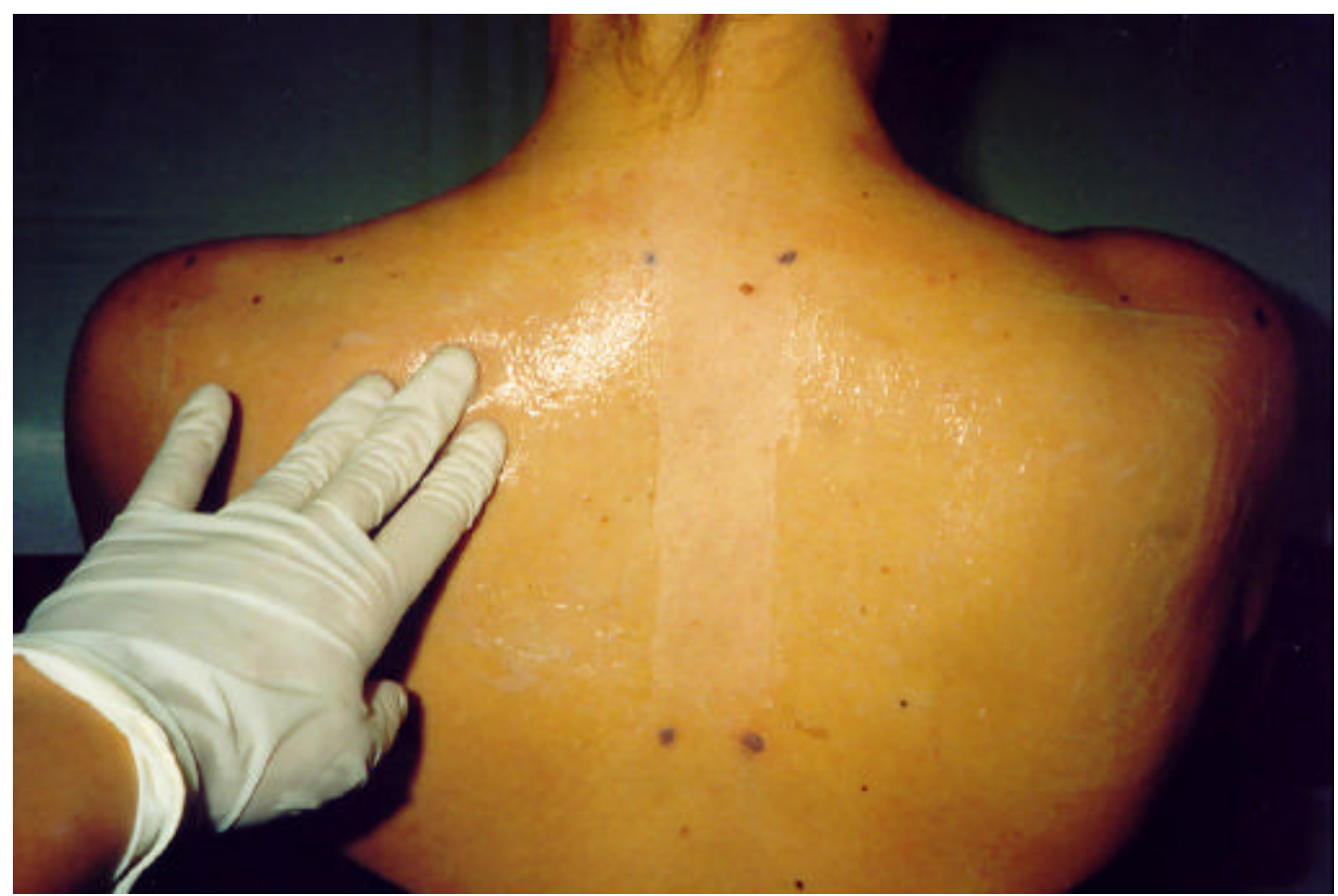

FIGURA 8. Aplicação do gel de diclofenaco sódico nas mesmas áreas. 


\subsection{Metodologia analítica e validação}

\subsubsection{Equipamento e condições cromatográficas}

A medida da concentração do diclofenaco sódico nas amostras de plasma foi realizada pela cromatografia líquida de alta eficiência (HPLC, ou high performance liquid chromatography), utilizando um equipamento Shimadzu (Kyoto, Japão) composto por uma bomba (LC-10AD), um detector ultra-violeta (UV $278 \mathrm{~nm}$ ), um injetor de $20 \mu \mathrm{l}$, um registrador (C-R6A Chromatopec) e um forno (CTO-6A). A separação cromatográfica foi realizada utilizando uma coluna C-18 Macherey-Nagel $5 \mu \mathrm{m}(250 \mathrm{~mm} \times 4.6$ $\mathrm{mm}$ ) (FIGURAS 09 e 10). A eluição foi realizada isocraticamente, a um fluxo de 1,0 $\mathrm{ml} /$ minuto, utilizando uma fase móvel acetonitrila-0,1 $\mathrm{M}$ acetato de sódio (35:65) e o pH foi ajustado para 6,3 com ácido acético glacial. Sob essas condições, o tempo de retenção do diclofenaco sódico foi em torno de 15 minutos.

\subsubsection{Reagentes}

$\mathrm{Na}$ etapa de análise pelo HPLC foram utilizados os reagentes: acetonitrila (Mallinckrodt), metanol (Mallinckrodt), álcool hexano (Merck), álcool isopropílico (Merck), ácido orto-fosfórico (Chemco), ácido acético glacial (Chemco) e acetato de sódio (Reagen Quimibrás Ind. Químicas S. A.).

A fase móvel consistiu de acetonitrila - 0,1 M acetato de sódio (35:65), com pH 6,3 ajustado com ácido acético glacial. 


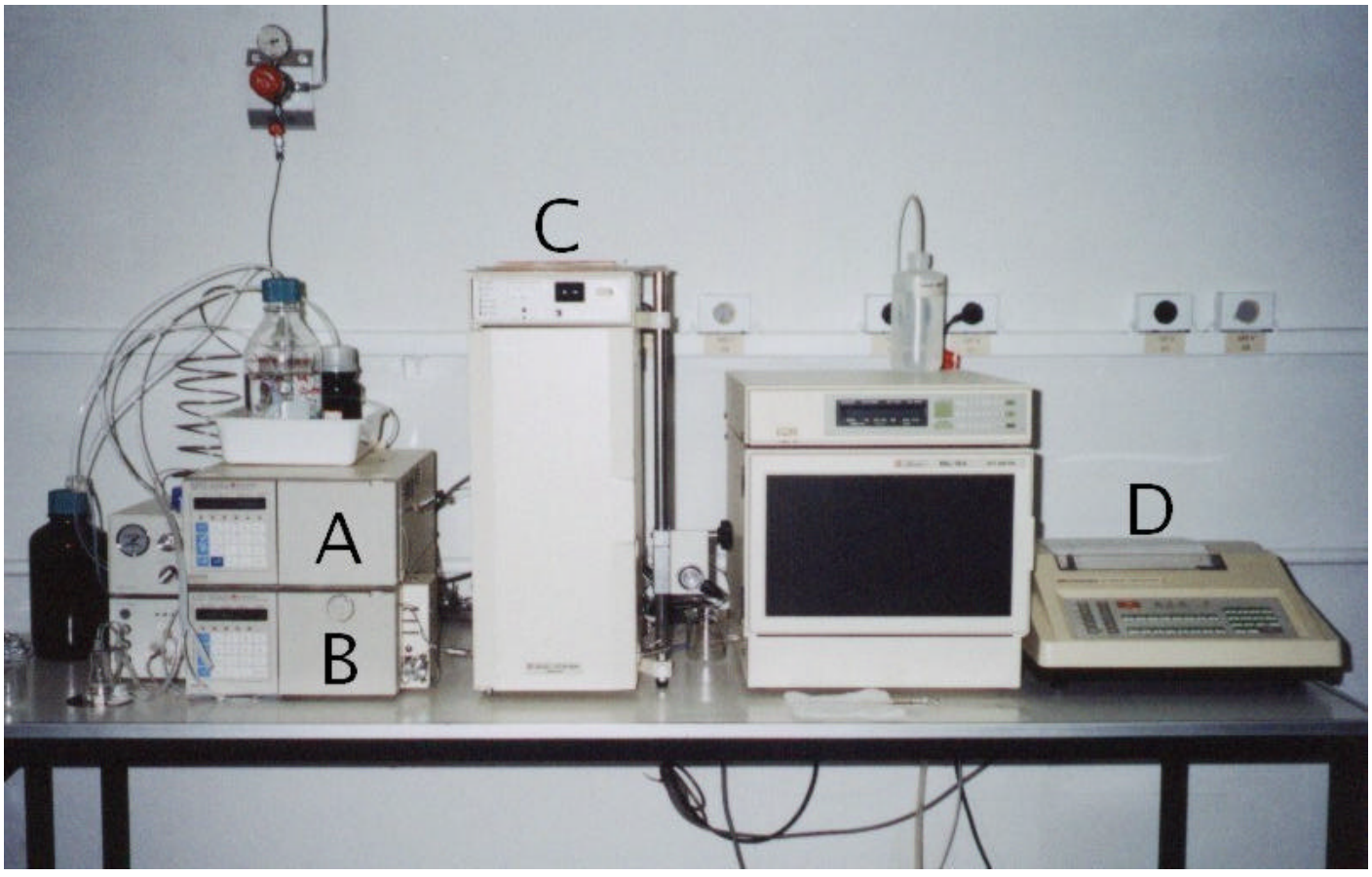

FIGURA 09. Equipamento de cromatografia líquida. A - Bomba; B - Detector; C - Forno com a coluna dentro; D - Registrador.

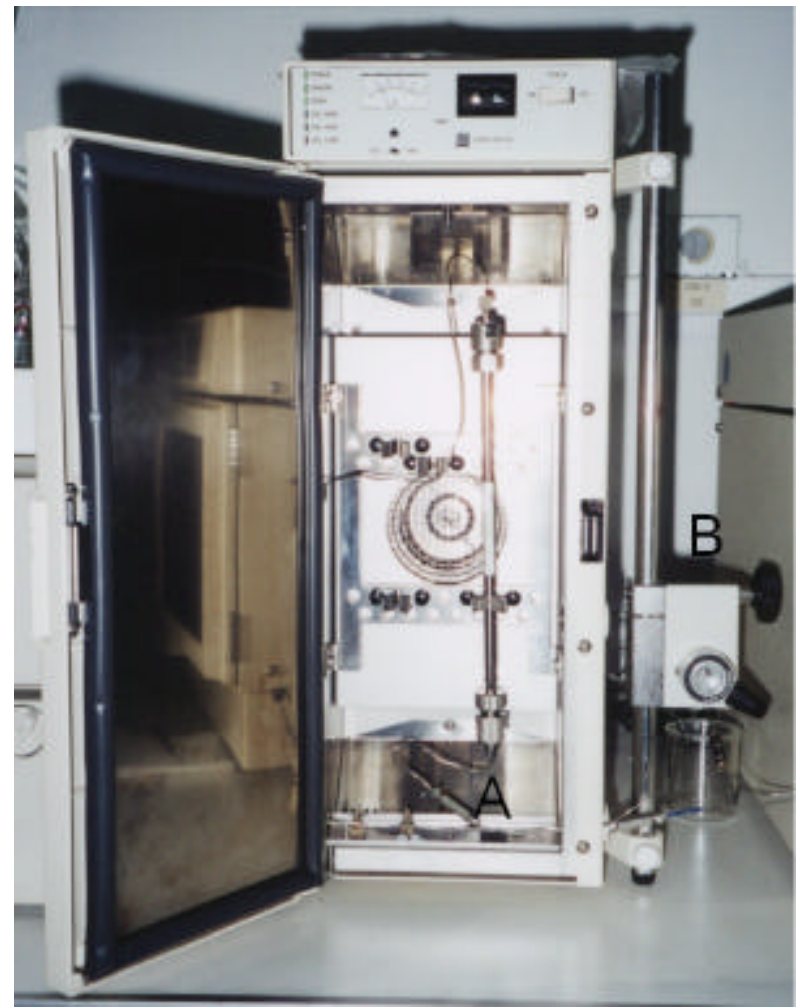

FIGURA 10. Detalhes da coluna cromatográfica dentro do forno $(A)$ e do injetor (B). 


\subsubsection{Padrão analítico e solução de estoque}

O padrão analítico do diclofenaco sódico, necessário para a calibração do equipamento e determinação das curvas de comparação, foi fornecido pelo fabricante do gel de diclofenaco sódico utilizado no estudo (Novartis Pharma Brasil, São Paulo, Brasil).

A solução de estoque do padrão analítico foi preparada dissolvendo o diclofenaco sódico em metanol, em uma proporção de $1 \mu \mathrm{g} / \mathrm{ml}$, e armazenada em refrigerador.

\subsubsection{Procedimentos de extração do diclofenaco sódico do} plasma

Foi utilizado o método cromatográfico descrito por GIAGOUDAKIS \& MARKANTONIS (1998). Inicialmente, foram obtidas curvas-padrão da extração do diclofenaco sódico do plasma, pela análise de soluções de concentração conhecida, preparadas pela adição de um volume correspondente a 0,0125, 0,025, 0,050,0,100,0,200 e 0,300 $\mu \mathrm{g} / \mathrm{ml}$ da solução-padrão a $225 \mu \mathrm{l}$ de plasma branco, em tubos de ensaio de $10 \mathrm{ml}$. Em seguida, foram adicionados $500 \mu$ de solução de ácido orto-fosfórico (2,5 M) a cada um dos tubos, que foram agitados por 20 segundos em um mixer (Mistral mod. 1190, Lab-Line Instruments). Seguiram-se a adição de 1,5 $\mathrm{ml}$ de uma mistura de álcool hexano e álcool isopropílico (80:20), agitação por 2,5 minutos e centrifugação (Centrífuga Excelsa Baby II, mod. 206-R, Fanen) por 10 minutos a 3000 rpm. A camada orgânica foi transferida para um tubo Eppendorf de 1,5 ml e submetida à evaporação sob fluxo de nitrogênio. O resíduo foi redissolvido em $250 \mu \mathrm{l}$ da fase móvel, ficando pronto para ser injetado manualmente no cromatógrafo, com um fluxo de 1,0 $\mathrm{ml} / \mathrm{min}$. Para cada preparação era obtido um cromatograma, no qual era identificado o pico correspondente ao diclofenaco sódico, ausente nos cromatogramas obtidos com o plasma branco. A área sob esse pico, obtida a partir da extração em plasma de uma quantidade conhecida do padrão 
analítico, correspondia ao valor da massa de diclofenaco extraída, sendo este o valor usado nas comparações. $O$ procedimento foi repetido duas vezes para cada concentração conhecida do padrão analítico, sendo daí obtida uma média para cada uma delas, que permitiu o estudo da correlação concentração-massa extraída (linearidade).

A extração do diclofenaco do plasma dos voluntários foi realizada executando os procedimentos de extração descritos acima, finalizando com uma injeção de cada amostra real no cromatógrafo. Conhecendo a área sob o pico do diclofenaco extraído das amostras reais dos pacientes, foi possível correlacionar a área com a concentração-massa, através da aplicação da equação da reta obtida a partir da curva-padrão.

\subsubsection{Linearidade e sensibilidade}

A linearidade foi testada utilizando as áreas medidas nas curvas de extração do padrão analítico do diclofenaco sódico diluído em plasma, nas concentrações de 0,025, 0,050, 0,100, 0,200 e 0,300 $\mu \mathrm{g} / \mathrm{ml}$, como referido acima. Observou-se que houve comportamento linear nas curvas de extração, com aumento da área correspondente ao aumento da concentração, com um coeficiente de relação de 0,999566 (TABELA 2 e FIGURA 11). A sensibilidade do método, ou seja, a menor concentração do padrão analítico extraído do plasma que pode ser diferenciado da linha de base do cromatograma, foi $0,001 \mu \mathrm{g} / \mathrm{ml}$. 
TABELA 2. Valores das áreas das curvas de extração do diclofenaco sódico (variação, média e desvio padrão) do plasma preparado, conforme as concentrações conhecidas do padrão analítico.

\begin{tabular}{ccccc}
\hline Ponto & $\begin{array}{c}\text { Concentração } \\
(\mu \mathrm{g} / \mathrm{ml})\end{array}$ & Área (variação) & Área média & Desvio Padrão \\
\hline 1 & 0,025 & 3,448 & 3,167 & 0,4 \\
& 2,885 & & 0,2 \\
\hline 2 & 0,050 & 6,280 & 6,156 & 0,6 \\
& & 6,031 & & 0,3 \\
\hline 3 & 0,100 & 10,986 & 11,412 & 1,6 \\
& & 11,837 & & \\
\hline 4 & 0,200 & 21,726 & 21,956 & \\
\hline 5 & 0,300 & 22,185 & & 31,449 \\
\end{tabular}

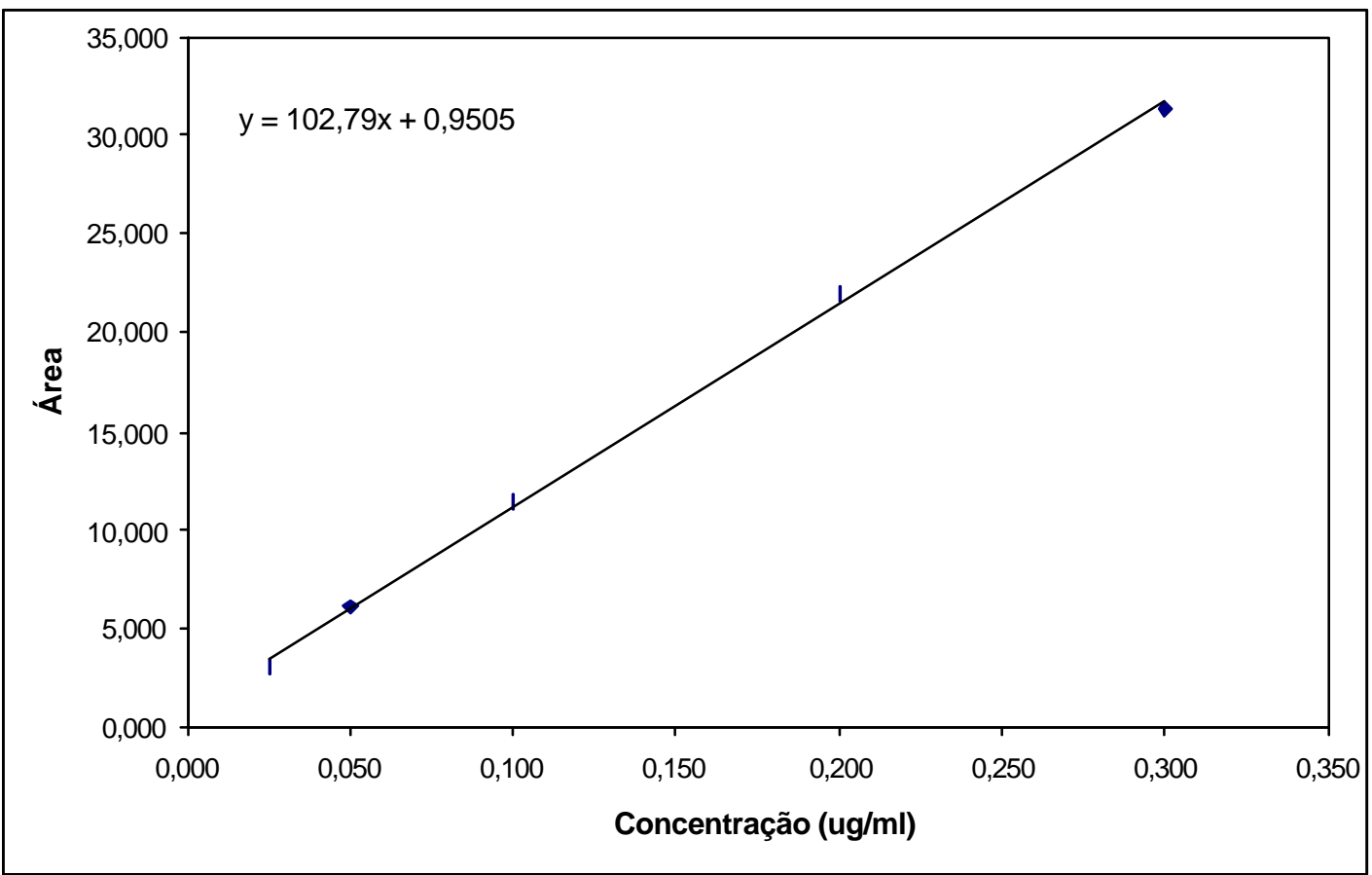

FIGURA 11. Curva de extração concentração $x$ área (coeficiente de relação da reta 0,999566$)$ para concentrações conhecidas do padrão analítico do diclofenaco sódico. 


\subsubsection{Precisão intra-dia e inter-dia e repetibilidade}

Para determinar a precisão do experimento em um mesmo dia (intradia) e entre dias diferentes (inter-dia), concentrações obtidas a partir das amostras de calibração foram analisadas.

Em um mesmo dia, a área média obtida a partir de duas injeções de uma mesma concentração foi $3,167( \pm 0,281)$, enquanto que a média obtida a partir de duas injeção de uma mesma concentração em dias diferentes foi $28,102( \pm 0,985)$ (TABELA 3).

TABELA 3. Precisão intra-dia (em um mesmo dia) e inter-dia (entre diferentes dias).

Precisão Intra-dia

\begin{tabular}{ccccc}
\hline Ponto & $\begin{array}{c}\text { Concentração } \\
(\mu \mathrm{g} / \mathrm{ml})\end{array}$ & Area & Área média & Desvio Padrão \\
\hline 1 & 0,025 & 3,448 & 3,167 & 0,4 \\
& 2,885 & & \\
\hline & & & & \\
& Precisão & Inter-dia & & 1,4 \\
\hline 2 & & & 28,102 & \\
\hline
\end{tabular}




\subsubsection{Taxa de Recuperação}

A taxa de recuperação mede a eficiência do procedimento de extração de um método analítico, dentro de um limite de variação. Taxas de recuperação próximas a 100\% são desejáveis, porém admitem-se valores menores, como 50 a 60\%, desde que a recuperação seja precisa.

A taxa de recuperação é obtida pela divisão da área do padrão extraído do plasma pela área do padrão dissolvido na fase móvel, multiplicada por 100 .

As taxas de recuperação obtidas neste experimento foram 82\%, 75\% e $87 \%$ para concentrações de diclofenaco de 0,025, 0,100 e 0,300 $\mu \mathrm{g} / \mathrm{mL}$, respectivamente, sendo a recuperação média de $81 \%$ (TABELA 4).

TABELA 4. Taxa de recuperação, de acordo com as concentrações conhecidas do diclofenaco sódico extraído do plasma e dissolvido na fase móvel.

\begin{tabular}{|c|c|c|c|c|c|c|}
\hline Ponto & $\begin{array}{c}\text { Concentração } \\
(\mu \mathrm{g} / \mathrm{ml})\end{array}$ & $\begin{array}{c}\text { Área } \\
\text { (Fase móvel) }\end{array}$ & $\begin{array}{l}\text { Área Média } \\
\text { (Fase móvel) }\end{array}$ & $\begin{array}{c}\text { Área } \\
\text { (Extração) }\end{array}$ & $\begin{array}{l}\text { Ārea Média } \\
\text { (Extração) }\end{array}$ & $\begin{array}{c}\text { Recuperação } \\
\text { (\%) }\end{array}$ \\
\hline \multirow[t]{2}{*}{1} & 0,025 & 3,918 & 3,849 & 3,448 & 3,167 & 82 \\
\hline & & 3,779 & & 2,885 & & \\
\hline \multirow[t]{2}{*}{2} & 0,100 & 16,215 & 15,279 & 10,986 & 11,412 & 75 \\
\hline & & 14,342 & & 11,837 & & \\
\hline \multirow[t]{3}{*}{3} & 0,300 & 37,623 & 35,946 & 30,305 & 31,449 & 87 \\
\hline & & 34,268 & & 32,593 & & Total \\
\hline & & & & & & 81 \\
\hline
\end{tabular}




\subsection{Análise estatística}

Foi realizada análise estatística dos resultados obtidos somente no Grupo A e somente no Grupo B e comparativamente entre os Grupos A e B. Para comparar os resultados obtidos nos Grupos A e B separadamente, considerando juntos os tempos de coleta da amostra de sangue, de 60, 120 e 180 minutos, foi aplicado o teste não paramétrico de Friedman aproximado para grandes amostras. Para comparar os resultados de A e B de acordo com cada tempo da coleta da amostra foi aplicado o teste não-paramétrico de Wilcoxon ou o teste de Wilcoxon para dados pareados, ambos com nível de significância de $5 \%(p<0,05)$ (HOLLANDER \& WOLFE, 1973). 


\section{RESULTADOS}

Todos os voluntários, exceto um no grupo de tratamento com ultrasom ligado, completaram o estudo. Os dados do voluntário que descontinuou o experimento foram excluídos.

Nenhum sintoma de irritação ou eritema foi observado na pele dos voluntários.

As figuras 12, 13, 14 e 15 são exemplos de cromatogramas obtidos após a injeção das amostras de plasma coletadas previamente, 60 minutos, 120 minutos e 180 minutos, respectivamente, após o experimento de um voluntário do grupo de tratamento com ultra-som ligado (Grupo A). O tempo de retenção do diclofenaco sódico pela coluna neste método utilizado foi de aproximadamente 15 minutos, quando aparece um pico correspondente à quantidade de diclofenaco no plasma. Os outros picos visualizados nos cromatogramas, que não foram identificados nesta ocasião, correspondem aos vários constituintes do plasma, que possui uma matriz complexa.

A figura 16 mostra um cromatograma obtido a partir de uma amostra de plasma branco que foi adicionada de $0,3 \mu \mathrm{g} / \mathrm{ml}$ da solução-padrão de estoque do padrão analítico. 


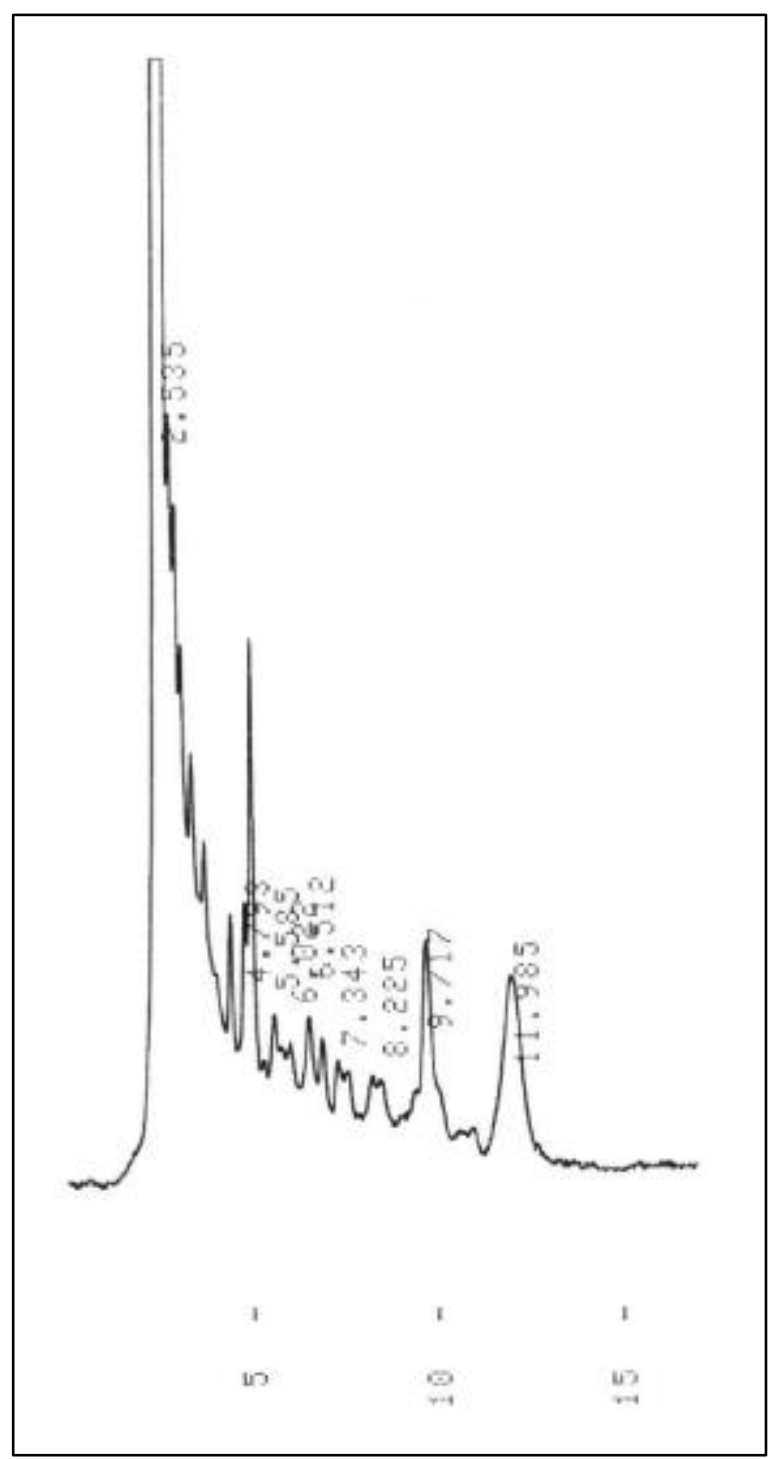

FIGURA 12. Cromatograma correspondente à amostra de sangue coletada previamente à aplicação do ultra-som e do Voltaren Emulgel ${ }^{\circledR}$. Notar a ausência de pico em 15 minutos. 


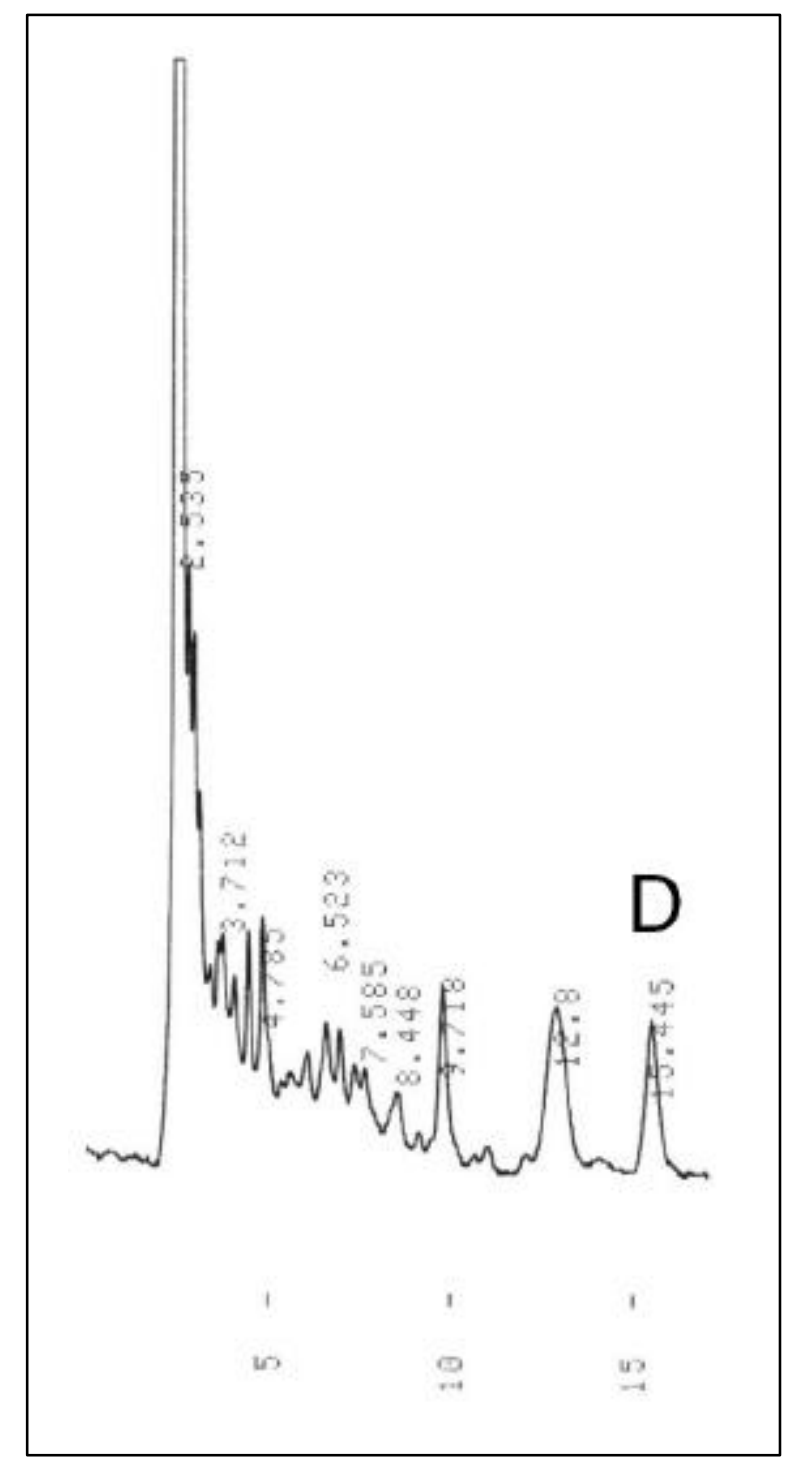

FIGURA 13. Cromatograma correspondente à amostra de sangue coletada 60 minutos após a aplicação do ultra-som e do Voltaren Emulgel ${ }^{\circledR}$ (pico D: diclofenaco). 


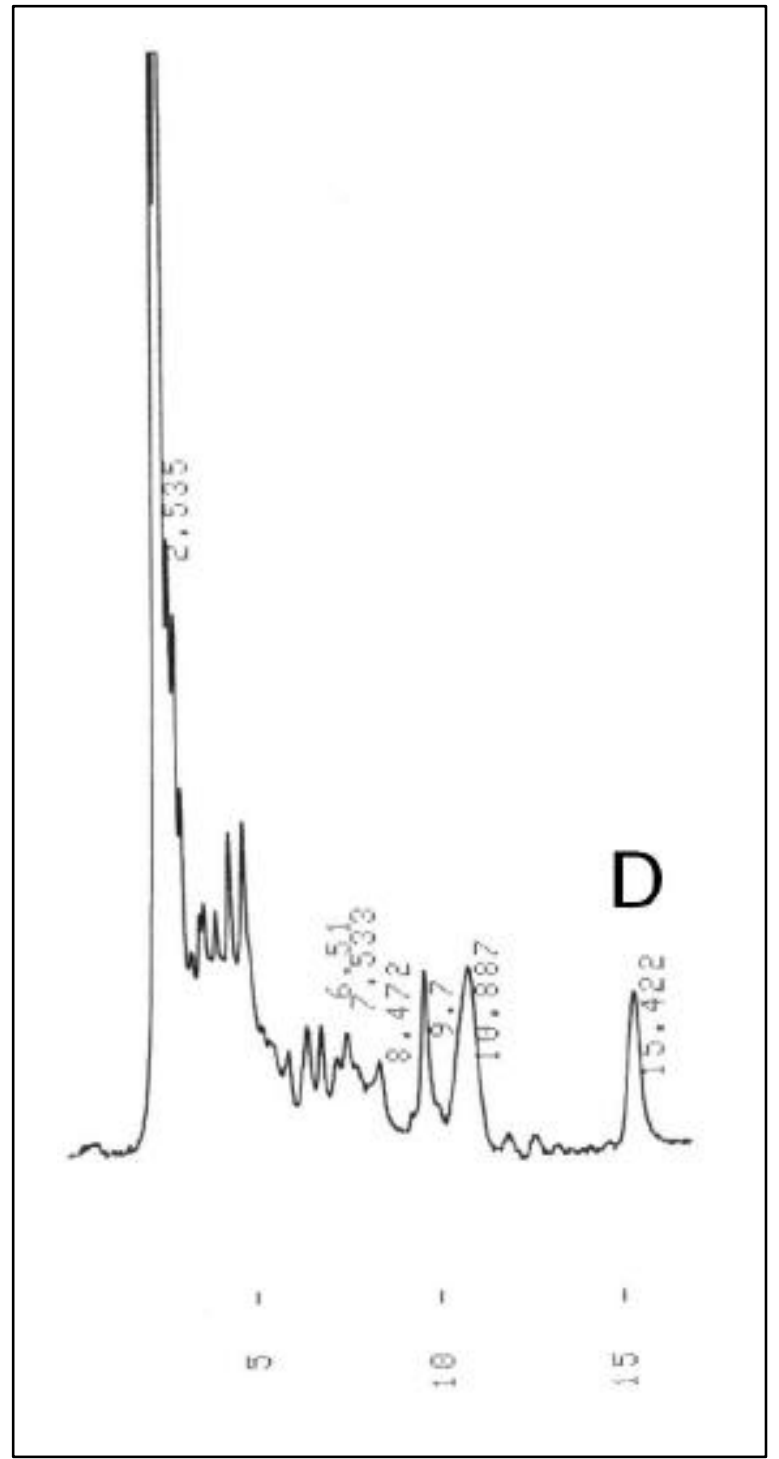

FIGURA 14. Cromatograma correspondente à amostra de sangue coletada 120 minutos após a aplicação do ultra-som e do Voltaren Emulgel ${ }^{\circledR}$ (pico D: diclofenaco). 


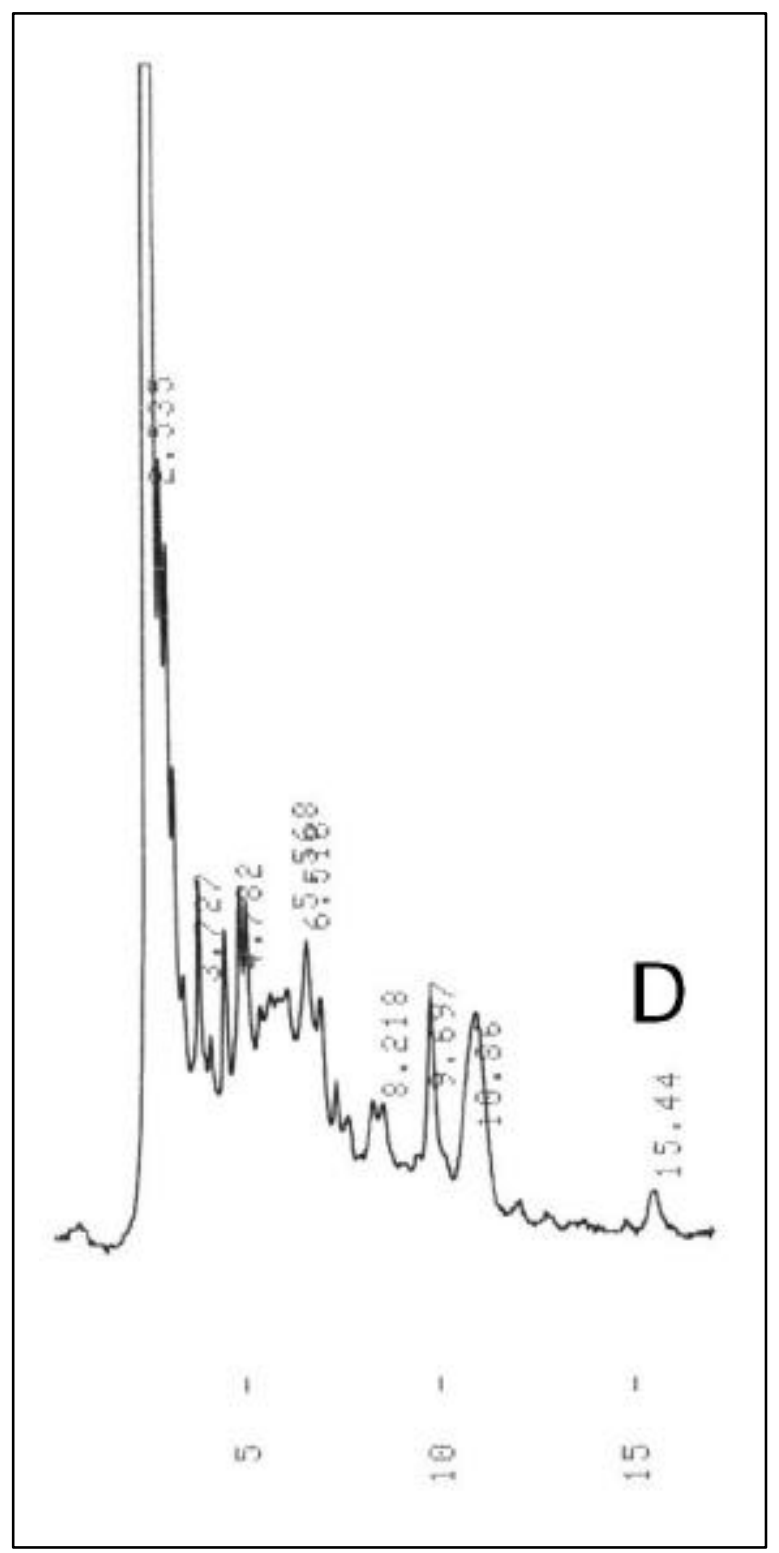

FIGURA 15. Cromatograma correspondente à amostra de sangue coletada 180 minutos após a aplicação do ultra-som e do Voltaren Emulgel ${ }^{\circledR}$ (pico D: diclofenaco). 


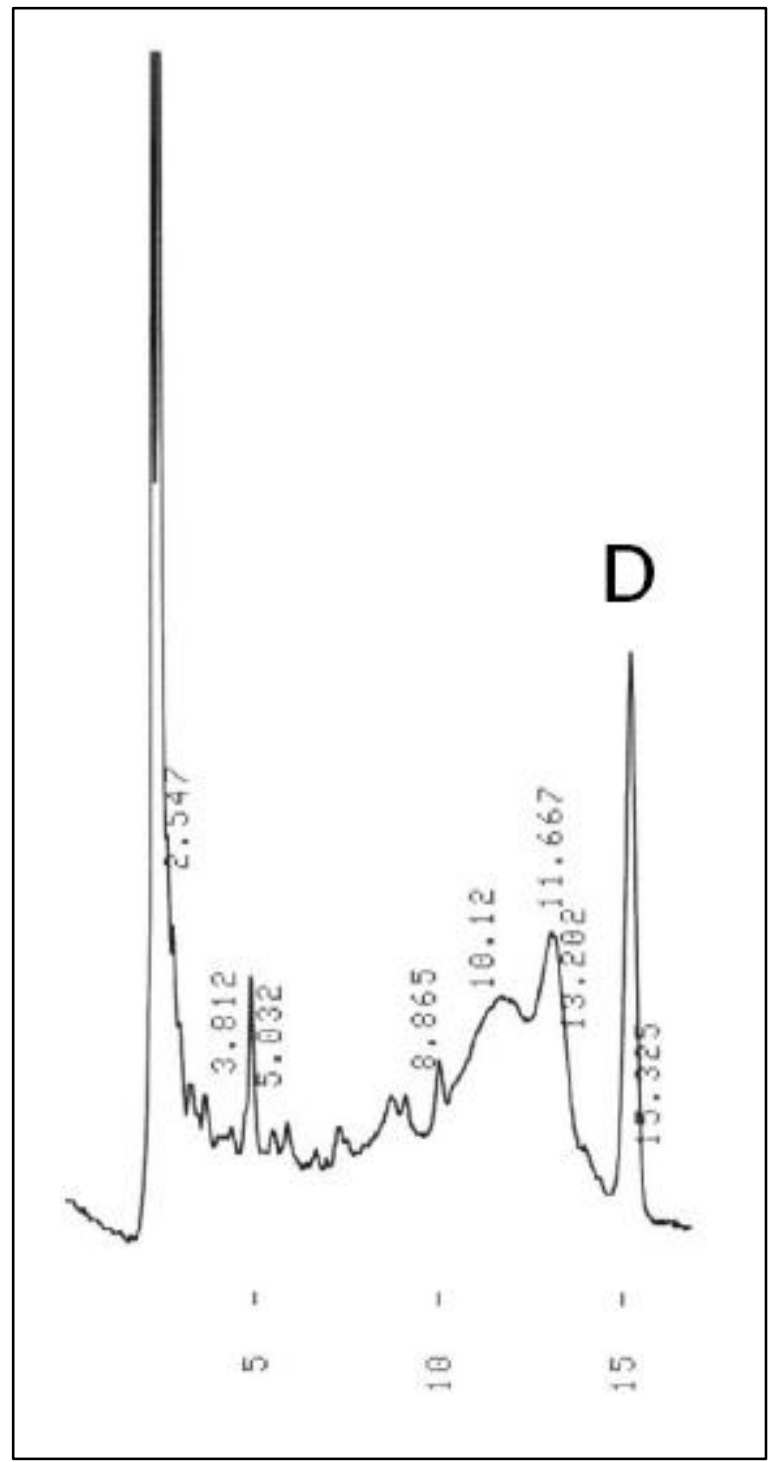

FIGURA 16. Cromatograma correspondente à amostra de plasma branco adicionada do padrão analítico do diclofenaco $(0,3 \mu \mathrm{g} / \mathrm{ml}$ da solução padrão de estoque) (pico D: diclofenaco). 
Foram analisados os resultados da massa de diclofenaco no plasma dos 14 voluntários, no Grupo A e no Grupo B, obtidos nos diferentes tempos de coleta de sangue de 60 minutos, 120 minutos e 180 minutos após 0 tratamento. Considerando esses tempos de coleta, no Grupo A, a massa, em $\mu \mathrm{g} / \mathrm{ml}$, passou de 0,0987 para 0,0724 e depois para 0,0864, respectivamente. No Grupo B, nesses mesmos períodos, a massa foi de 0,0389, 0,0529 e 0,0683, respectivamente.

Nas tabelas 5 a 7 podem ser visualizados os valores de área sob a curva, através dos quais foi possível calcular o valor da massa de diclofenaco de cada amostra, com os respectivos percentis $25 \%, 50 \%$ (mediana) e 75\%, média, desvio padrão e fator de facilitação, que corresponde ao valor médio da massa de diclofenaco do Grupo A em relação ao valor médio do Grupo B. O fator de facilitação demonstra que 0 valor médio da penetração de diclofenaco através da pele dos pacientes no Grupo A foi 2,2 vezes maior que no Grupo B após 60 minutos do tratamento.

Nas figuras 17 a 21 estão as representações gráficas dos valores de massa de diclofenaco encontrada nos grupos A e B, na forma de box plots, onde as bordas inferior e superior correspondem, respectivamente, aos primeiro e terceiro quartis, à linha interna, à mediana, os colchetes horizontais externos, ao menor e maior valores da amostra, e as linhas horizontais isoladas abaixo e acima, aos valores $1,5 \mathrm{vez}$ o primeiro e 0 terceiro quartis, respectivamente.

A tabela 5 e a figura 17, correspondentes æ̀̀ amostras de sangue coletadas após 60 minutos do procedimento, demonstram que houve diferença significante entre os valores de massa de diclofenaco entre os grupos $A$ e $B(p=0,01)$. A tabela 6 e a figura 18 , correspondentes ঝ̀ amostras de sangue coletadas após 120 minutos do procedimento, também demonstram que houve diferença significante entre os valores de massa de diclofenaco entre os grupos A e B $(p=0,01)$, diferente dos valores de massa observados após 180 minutos, quando não houve diferença significante entre os valores de massa de diclofenaco entre os grupos $A$ e $B(p=0,16)$ (TABELA 7 e FIGURA 19). 
Conforme está demonstrado nas figuras 20 e 21, a análise por grupo não mostrou diferenças significantes entre os valores obtidos quando considerados os diferentes tempos de coleta de sangue dentro de um mesmo grupo, seja no Grupo A ( $p=0,11)$, seja no Grupo B $(p=0,22)$. 
TABELA 5 - Valores da área sob o pico do diclofenaco e correspondentes valores da massa plasmática, obtidos a partir das amostras de plasma coletadas após 60 minutos do procedimento.

\begin{tabular}{ccccc}
\hline VOLUNTÁRIO & \multicolumn{2}{c}{ ÁREA } & \multicolumn{3}{c}{ MASSA DICLOFENACO $(\boldsymbol{\mu} \mathbf{g} / \mathbf{m L})$} \\
\cline { 2 - 5 } (60 minutos) & A & $\mathbf{B}$ & $\mathbf{A}$ & $\mathbf{B}$ \\
\hline 1 & 11,197 & 10,415 & 0,0997 & 0,0921 \\
2 & 16,568 & 2,160 & 0,1519 & 0,0118 \\
3 & 10,982 & 5,824 & 0,0976 & 0,0474 \\
4 & 11,952 & 6,914 & 0,1070 & 0,0580 \\
5 & 10,624 & 0 & 0,0941 & 0 \\
6 & 12,998 & 0 & 0,1172 & 0 \\
7 & 5,889 & 18,205 & 0,0480 & 0,1679 \\
8 & 11,610 & 5,447 & 0,1037 & 0,0437 \\
9 & 16,373 & 0 & 0,1500 & 0 \\
10 & 6,000 & 10,599 & 0,0491 & 0,0939 \\
11 & 6,921 & 3,195 & 0,0581 & 0,0218 \\
12 & 10,343 & 0 & 0,0914 & 0 \\
13 & 8,006 & 5,411 & 0,0686 & 0,0434 \\
14 & 11,245 & 4,486 & 0,1001 & 0,0344 \\
\hline P25 & 8,006 & 0 & 0,0686 & 0 \\
P50 & 11,090 & 4,949 & 0,0987 & 0,0389 \\
P75 & 11,952 & 6,914 & 0,1070 & 0,0580 \\
Média & 10,765 & 5,190 & 0,0955 & 0,0439 \\
Desvio padrão & 3,302 & 5,195 & 0,0321 & 0,0478 \\
\hline Fator de facilitação & \multicolumn{3}{c}{2,2} \\
\hline
\end{tabular}

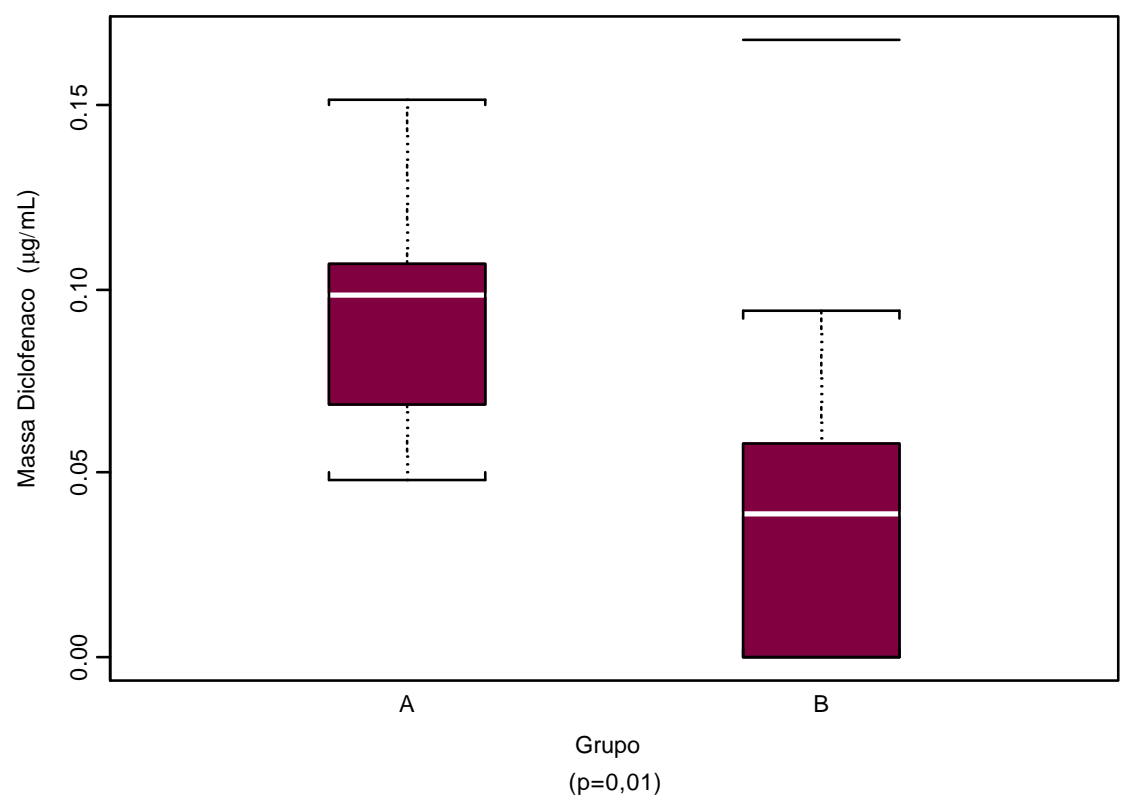

FIGURA 17. Comparação dos resultados dos grupos A e B a partir dos resultados obtidos das amostras coletadas após 60 minutos do procedimento. $p=0,01$. 
TABELA 6 - Valores da área sob o pico do diclofenaco e correspondentes valores da massa plasmática, obtidos a partir das amostras de plasma coletadas após 120 minutos do procedimento.

\begin{tabular}{ccccc}
\hline VOLUNTÁRIO & \multicolumn{2}{c}{ ÁREA } & \multicolumn{2}{c}{ MASSA DICLOFENACO $(\boldsymbol{\mu} \mathbf{g} / \mathbf{m L})$} \\
\cline { 2 - 5 } (120 minutos) & A & B & A & B \\
\hline 1 & 7,987 & 2,161 & 0,0685 & 0,0118 \\
2 & 9,010 & 0 & 0,0784 & 0 \\
3 & 7,964 & 8,475 & 0,0682 & 0,0732 \\
4 & 10,542 & 6,819 & 0,0933 & 0,0571 \\
5 & 3,210 & 8,254 & 0,0220 & 0,0711 \\
6 & 12,350 & 7,089 & 0,1109 & 0,0597 \\
7 & 8,096 & 9,292 & 0,0695 & 0,0811 \\
8 & 9,674 & 5,947 & 0,0849 & 0,0486 \\
9 & 7,167 & 9,102 & 0,0605 & 0,0793 \\
10 & 14,493 & 8,597 & 0,1317 & 0,0744 \\
11 & 7,818 & 5,483 & 0,0668 & 0,0441 \\
12 & 8,679 & 5,072 & 0,0752 & 0,0401 \\
13 & 7,961 & 4,787 & 0,0682 & 0,0373 \\
14 & 11,720 & 4,547 & 0,1048 & 0,0350 \\
\hline P25 & 7,961 & 4,787 & 0,0682 & 0,0373 \\
P50 & 8,388 & 6,383 & 0,0724 & 0,0529 \\
P75 & 10,542 & 8,597 & 0,0933 & 0,0732 \\
Média & 9,048 & 6,116 & 0,0788 & 0,0509 \\
Desvio padrão & 2,689 & 2,711 & 0,0261 & 0,0248 \\
\hline Fator de facilitação & \multicolumn{3}{c}{1,5} & \\
\hline
\end{tabular}

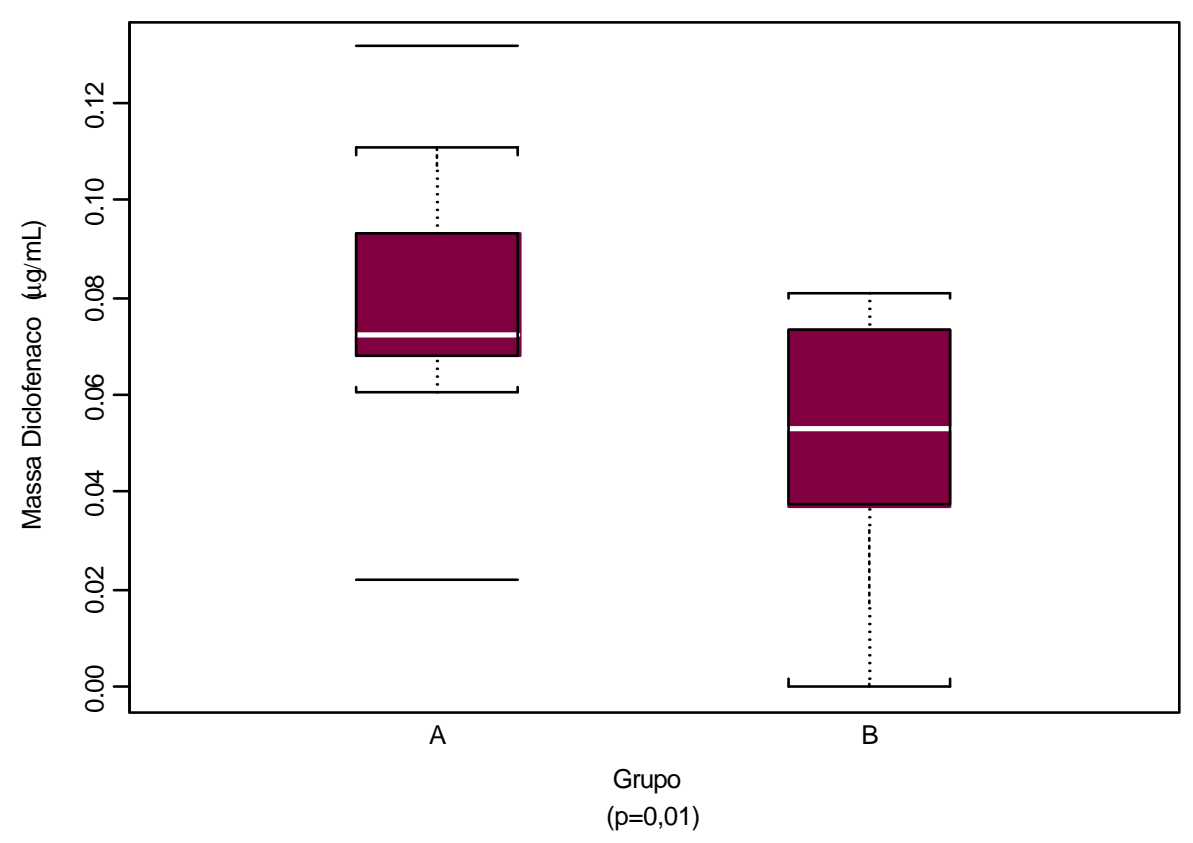

FIGURA 18. Comparação dos resultados dos grupos A e B a partir dos resultados das amostras obtidas após 120 minutos de procedimento. $p=0,01$. 
TABELA 7 - Valores da área sob o pico do diclofenaco e correspondentes valores da massa plasmática, obtidos a partir das amostras de plasma coletadas após 180 minutos do procedimento.

\begin{tabular}{ccccc}
\hline VOLUNTÁRIO & \multicolumn{2}{c}{ ÁREA } & \multicolumn{2}{c}{ MASSA DICLOFENACO $(\boldsymbol{\mu} \mathbf{g} / \mathbf{m L})$} \\
\cline { 2 - 5 } (180 minutos) & A & B & A & B \\
\hline 1 & 9.321 & 21.281 & 0.0814 & 0.1978 \\
2 & 10.492 & 4.566 & 0.0928 & 0.0352 \\
3 & 9.418 & 10.816 & 0.0824 & 0.0960 \\
4 & 11.673 & 4.615 & 0.1043 & 0.0356 \\
5 & 5.928 & 5.684 & 0.0484 & 0.0460 \\
6 & 3.503 & 10.758 & 0.0248 & 0.0954 \\
7 & 12.328 & 10.852 & 0.1107 & 0.0963 \\
8 & 9.594 & 8.143 & 0.0841 & 0.0700 \\
9 & 12.761 & 7.426 & 0.1149 & 0.0630 \\
10 & 9.044 & 9.471 & 0.0787 & 0.0829 \\
11 & 11.096 & 2.856 & 0.0987 & 0.0185 \\
12 & 11.508 & 4.060 & 0.1027 & 0.0302 \\
13 & 7.710 & 9.300 & 0.0658 & 0.0812 \\
14 & 10.066 & 7.799 & 0.0887 & 0.0666 \\
\hline P25 & 9,044 & 4,615 & 0,0787 & 0,0356 \\
P50 & 9,830 & 7,971 & 0,0864 & 0,0683 \\
P75 & 11,508 & 10,758 & 0,1027 & 0,0954 \\
Média & 9,603 & 8,402 & 0,0842 & 0,0725 \\
Desvio padrão & 2,531 & 5,580 & 0,0246 & 0,0446 \\
\hline Fator de facilitação & \multicolumn{3}{c}{1,2} & \\
\hline
\end{tabular}

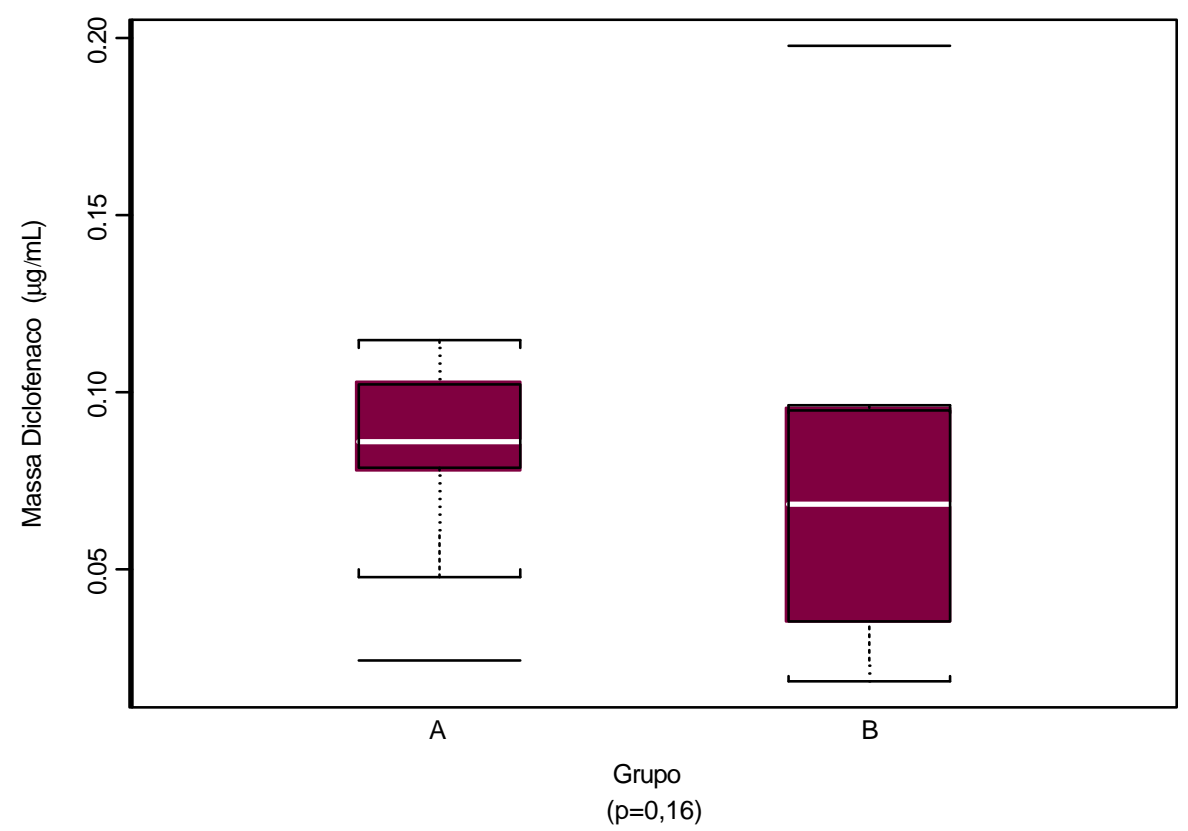

FIGURA 19. Comparação dos resultados dos grupos $A$ e $B$ a partir dos resultados obtidos das amostras coletadas após 180 minutos do procedimento. $p=0,16$. 


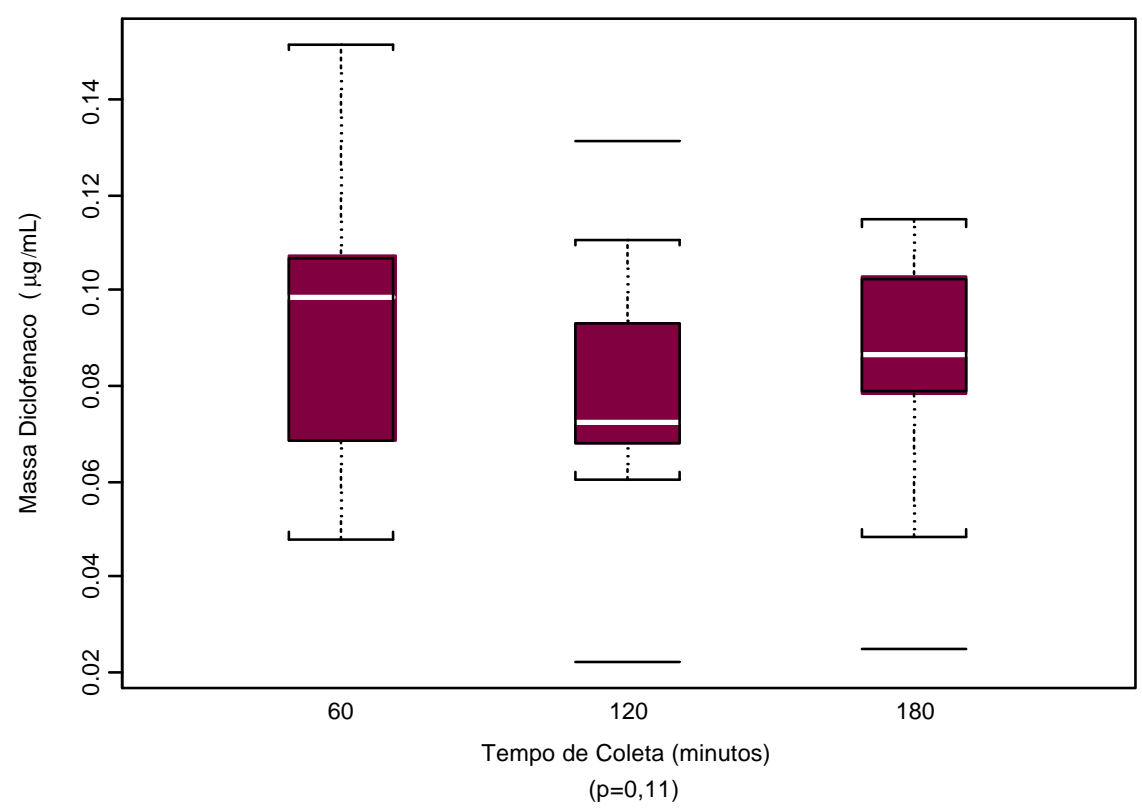

FIGURA 20. Comparação dos resultados somente do Grupo A obtidos das amostras coletadas após 60,120 e 180 minutos do procedimento. $p=0,11$.

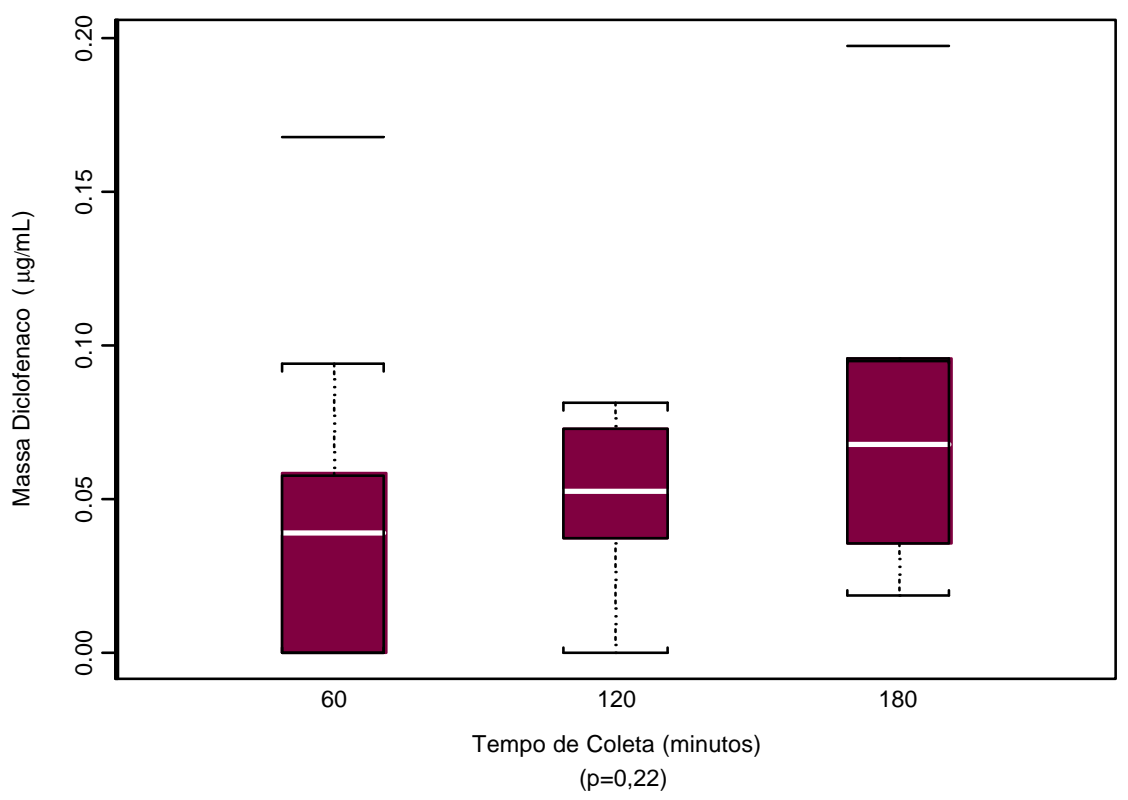

FIGURA 21. Comparação dos resultados somente do Grupo B obtidos das amostras coletadas após 60, 120 e 180 minutos do procedimento. p=0,22. 


\section{DISCUSSÃO}

Tanto o ultra-som terapêutico como os antiinflamatórios nãohormonais são recursos amplamente utilizados em fisioterapia e medicina do esporte para o tratamento de uma variedade de condições, em especial patologias músculo-esqueléticas, reumáticas e lesões de tecidos moles, æ̀ vezes separadamente, ’̀s vezes conjuntamente, geralmente com efeitos benéficos.

O uso dos antiinflamatórios por via sistêmica (oral ou parenteral) está associado a uma incidência variável de efeitos colaterais indesejáveis, como a gastrite medicamentosa, fato que certamente influenciou no desenvolvimento de formulações tópicas, em geral na forma de géis ou cremes, os quais, todavia, são de mais difícil absorção através da pele e não apresentam os mesmos resultados que por via sistêmica. A via de administração transcutânea de antiinflamatórios tem despertado grande interesse por parte dos investigadores por possuir algumas vantagens em relação à administração oral, particularmente do diclofenaco sódico, na qual grande parte da dose administrada é rapidamente retirada no metabolismo de primeira passagem e produz efeitos colaterais às vezes perigosos, como reações gastrintestinais, com formação até de ulcerações gástrica e duodenal e conseqüentes hemorragias (MÜLLER et al., 1997).

O emprego concomitante de antiinflamatórios tópicos na forma de gel e ultra-som terapêutico é uma prática comum pelos profissionais de reabilitação, sob a alegação de que este último favorece a penetração transcutânea do primeiro, de forma quase totalmente empírica, pois ainda não havia comprovação laboratorial desse fato.

Todavia, há evidências de que o ultra-som realmente favorece a penetração transcutânea de vários fármacos, como os corticosteróides dexametasona e hidrocortisona, em animais (BYL et al., 1993), vasodilatador metil-nicotinato em humanos saudáveis (McELNAY et al., 1993), proteínas insulina, interferon e eritropoetina (MITRAGOTRI et al., 1995) e antiinflamatório indometacina, em animais (ASANO et al., 1997). O 
antiinflamatório diclofenaco sódico, na forma gel de uso tópico, foi investigado por EL-HADIDI \& EL-GARF (1991), que realizaram um estudo de investigação clínica em pacientes, mas com critérios de avaliação excessivamente subjetivos, como a dor à pressão e ao movimento, graduada por meio de uma escala analógica de dor.

No presente estudo, também foi investigada a penetração transcutânea de diclofenaco sódico, especificamente o Voltaren Emulge ${ }^{\circledR}$, porém desta vez em voluntários saudáveis e através da quantificação da massa de diclofenaco no plasma dos voluntários por cromatografia líquida de alta eficiência.

O diclofenaco sódico foi eleito por ser um AINH consagrado, que apresenta efeitos antiinflamatórios e analgésicos em um período de tempo relativamente curto, o que é particularmente importante para atletas que precisam retornar ao treinamento o mais rápido possível após uma lesão (EL-HADIDI \& EL-GARF, 1991).

A decisão pelo emprego de voluntários humanos saudáveis teve por objetivo aproximar o máximo possível o estudo da prática clínica e quantificar fielmente a massa de diclofenaco sódico presente no plasma após aplicação transcutânea do medicamento, sem a influência de fatores que foram indesejados, considerados como critérios de exclusão. Baseouse, também, no fato de que vários autores utilizaram-se de voluntários saudáveis para o estudo da farmacocinética do diclofenaco (SIOUFI et al., 1994; HAMED et al., 1994; MULLER et al., 1997; HUl et al., 1998; SENGUPTA et al., 1998).

O emprego dos voluntários como controles de si mesmos, com a realização de duas sessões de tratamento com intervalo de um mês, sendo a segunda com o equipamento inativo, foi a maneira mais eficiente de minimizar a variabilidade entre os indivíduos, devido à propriedades individuais da pele.

A opção por fazer o tratamento da pele com ultra-som previamente à aplicação do gel de diclofenaco sódico, ao invés de utiliza-lo como gel de acoplamento do cabeçote ultra-sônico, foi baseada nas considerações de 
BENSON \& McELNAY (1994), que pesquisaram as características de transmissão de vários produtos diferentes e encontraram muita variação na resposta a cada um. A transmissividade do ultra-som aumenta com a sua freqüência e, com base nisso, esses autores consideraram que freqüências altas de ultra-som podem causar quebra nas cadeias de polímeros que conferem a viscosidade dos agentes utilizados nas formulações tópicas. Antes da escolha de uma formulação tópica para contato e acoplamento do cabeçote ultra-sônico, há a necessidade de investigações quanto aos efeitos do ultra-som na sua estrutura interna e viscosidade, caso contrário os resultados da sonoforese podem ser alterados e a terapia realizada tornar-se ineficaz. Além disso, os fabricantes de equipamentos de ultra-som afirmam que géis medicamentosos viscosos não transmitem adequadamente as ondas ultra-sônicas, causando reflexão das mesmas, o que leva ao aquecimento anormal do cabeçote, podendo danifica-lo (LONGO \& FUIRINI, 2002) .

McELNAY et al. (1993) já haviam realizado sonoforese com prétratamento da pele e observaram que a penetração da droga ocorre por um período após a cessação do tratamento com ultra-som, do mesmo modo como observado no presente estudo. Concluíram que a energia do ultra-som é capaz de afetar a estrutura da pele, o que explicaria o aumento da penetração transcutânea de medicamentos sob influência do ultra-som.

A região dorsal para aplicação do ultra-som e do gel de diclofenaco sódico foi eleita por apresentar menor quantidade de pêlos, em comparação com os membros superiores e inferiores. A determinação das duas áreas de aplicação do tratamento, uma de cada lado da região dorsal, o volume de gel aplicado e a aplicação única do gel para mensuração da conseqüente concentração plasmática foram baseados no estudo da farmacocinética do diclofenaco realizado por SIOUFI et al. (1994).

Os parâmetros eleitos para o ultra-som, ou seja, contínuo, com freqüência de $1 \mathrm{MHz}$, intensidade de $0,5 \mathrm{~W} / \mathrm{cm}^{2}$ e aplicação por 5 minutos, são parâmetros comumente utilizados em propostas terapêuticas. A

\footnotetext{
• LONGO, G; FUIRINI, N. (2002) Ultra-som e gel medicamentoso. E-mail. (2 Mai. 2002).
} 
intensidade escolhida para investigação é uma vez menor que aquela investigada por McELNAY et al. (1993) e duas vezes menor que a investigada por BYL et al. (1993), ROBINSON \& BUONO (1995) e KLAIMAN et al. (1998). A escolha por uma intensidade baixa foi baseada em estudos realizados em animais; no estudo realizado em ratos por ASANO et al. (1997), os autores constataram aumento da temperatura e necrose tecidual com ultra-som contínuo e intensidade de $1,0 \mathrm{~W} / \mathrm{cm}^{2}$, efeitos estes não observados com a intensidade de $0,5 \mathrm{~W} / \mathrm{cm}^{2}$ por 10 minutos. No estudo realizado em peixes por FRENKEL et al. (1999), os autores constataram os primeiros sinais de danos teciduais com ultra-som contínuo e intensidade de $0,75 \mathrm{~W} / \mathrm{cm}^{2}$, efeitos estes não observados até $0,5 \mathrm{~W} / \mathrm{cm}^{2}$.

A coleta do sangue de veias do antebraço dos indivíduos, nos tempos pré-estabelecidos, bi eleita por ser uma prática comum e usualmente sem intercorrências em laboratórios de análises clínicas, para realização de exames de curva da glicemia. Além disso, é esta a forma que vários autores utilizaram para estudos sobre a farmacocinética de medicamentos em voluntários (SIOUFI et al., 1994; HAMED et al., 1994; HUl et al., 1998; SENGUPTA et al., 1998).

Vários métodos de cromatografia líquida de alta eficiência têm sido empregados por mais de 16 anos para determinação da massa de diclofenaco no plasma sanguíneo (GIAGOUDAKIS \& MARKANTONIS, 1998) e foi a metodologia de avaliação escolhida nos estudos de KUROWSKI \& DUNKY (1992), HAMED et al. (1994), ASANO et al. (1997), GIAGOUDAKIS \& MARKANTONIS (1998) e SENGUPTA et al. (1998), sendo que desses estudos, somente aquele realizado por ASANO et al. (1997) envolve a investigação da sonoforese, mas com a indometacina.

O método cromatográfico para quantificação da massa de diclofenaco em plasma empregado neste estudo foi o proposto por GIAGOUDAKIS \& MARKANTONIS (1998) e demonstrou ser capaz de quantificar, em $\mu \mathrm{g} / \mathrm{ml}$, a massa de diclofenaco sódico presente no plasma de voluntários após a aplicação transcutânea de gel de diclofenaco sódico. O método fornece um valor numérico passível de análise estatística e confiável, tendo em vista sua 
validação, realizada neste estudo através da obtenção de uma curva analítica ou de um gráfico de calibração, a partir da análise da extração do fármaco de volumes conhecidos de plasma branco adicionado de concentrações conhecidas do padrão analítico do diclofenaco sódico, com o mesmo método e equipamento de cromatografia.

O efeito positivo da sonoforese sobre a absorção transcutânea de fármacos foi confirmado por praticamente todos os trabalhos revisados, inclusive com significância estatística, apesar das diferenças na metodologia de avaliação. A exceção foi o estudo realizado por KLAIMAN et al. (1998), que demonstrou não haver diferenças entre os pacientes tratados somente com o ultra-som terapêutico e aquele acompanhado da aplicação de um corticoesteróide, apesar de ambos os grupos terem demonstrado melhora significativa do nível de dor quando comparados com um grupo controle.

A investigação sobre sonoforese que mais se aproxima do presente estudo foi a realizada por ASANO et al. (1997), que investigaram em ratos a influência do ultra-som na penetração transcutânea de indometacina, um antiinflamatório não-hormonal assim como o diclofenaco, utilizando também a cromatografia líquida de alta eficiência como método de avaliação. Durante um período de 4 horas após o tratamento, a absorção média do fármaco foi 1,8 vez maior no grupo tratado com o ultra-som (contínuo, com freqüência de $1 \mathrm{MHz}$, intensidade de $0,5 \mathrm{~W} / \mathrm{cm}^{2}$ e aplicação por 10 minutos) do que no grupo controle. No presente estudo, após 1 hora do tratamento, a absorção média do diclofenaco sódico foi 2,2 vezes maior no grupo tratado do que no grupo controle, caindo progressivamente nos períodos posteriores.

É difícil saber se as concentrações de diclofenaco sódico aqui mensuradas no plasma dos voluntários estariam associadas aos efeitos terapêuticos da droga. GIAGOUDAKIS \& MARKANTONIS (1998), além de descreverem o método cromatográfico utilizado no presente estudo, realizaram uma aplicação clínica do mesmo método, extraindo diclofenaco do plasma de voluntários sadios após administração oral de $50 \mathrm{mg}$ de Voltaren ${ }^{\circledR}$. Eles obtiveram concentrações máximas de diclofenaco de 743 $\mathrm{ng} / \mathrm{ml}$, ou seja, aproximadamente cinco vezes mais altas do que as 
concentrações máximas mensuradas no presente estudo. Segundo RADERMACHER et al. (1991), o diclofenaco é relativamente potente quando comparado com outros antiinflamatórios não-hormonais e concentrações plasmáticas da ordem de $100 \mathrm{ng} / \mathrm{ml}$ já são associadas aos efeitos terapêuticos da droga.

Resta discutir os mecanismos de ação envolvidos na facilitação ultrasônica da penetração transcutânea de fármacos, que ainda não estão totalmente esclarecidos, mas autores dedicados ao tema aventam a hipótese de que seja a cavitação a responsável pelo fenômeno (BYL et al., 1993; McELNAY et al., 1993; MITRAGOTRI et al., 1995). Outra possibilidade seria o aumento do fluxo sanguíneo local da aplicação do ultrasom, mas esse mecanismo parece improvável, tendo em vista os resultados dos experimentos de ASANO et al. (1997) e de ROBINSON \& BUONO (1994). Os primeiros demonstraram que o ultra-som contínuo de $1 \mathrm{MHz}$ de freqüência e intensidade de $0,5 \mathrm{~W} / \mathrm{cm}^{2}$, aplicado por 10 minutos, promoveu um aumento significativo da penetração de indometacina, sem interferir com a temperatura hipodérmica, monitorada por meio de termistores; os segundos, demonstraram que o ultra-som contínuo, de $1 \mathrm{MHz}$ de freqüência e $1,5 \mathrm{~W} / \mathrm{cm}^{2}$ de intensidade, aplicado por 5 minutos, não aumentou significativamente o fluxo sanguíneo no antebraço de voluntários, monitorado por meio de fluxometria pelo Doppler a laser.

Logo, em não havendo aumento do fluxo sanguíneo com o conseqüente aumento da temperatura, parece mais provável que a cavitação seja o principal mecanismo da facilitação pelo ultra-som da penetração transcutânea do diclofenaco sódico. Os resultados da presente investigação parecem corroborar essa hipótese, pois houve facilitação significativa da absorção transcutânea do diclofenaco sódico com a irradiação ultra-sônica prévia, apesar da baixa intensidade $\left(0,5 \mathrm{~W} / \mathrm{cm}^{2}\right)$ e do tempo de aplicação relativamente curto (5 minutos) de cada lado. Embora a temperatura hipodérmica não tenha sido monitorada, sabemos que a energia sonora é convertida em energia térmica proporcionalmente à intensidade do ultra-som e na intensidade empregada os efeitos térmicos são quase que 
desprezíveis. Em segundo lugar, o gel de diclofenaco sódico foi aplicado após a cessação da irradiação com o ultra-som, o que leva a acreditar que eventuais aumentos da temperatura local possam ter sido rapidamente dissipados pelos mecanismos fisiológicos normais e que a facilitação da absorção tenha ocorrido por alteração da estrutura cutânea pela cavitação, o que de fato ocorre, como demonstrado por McELNAY et al. (1993).

Entretanto, a proposta do presente trabalho foi apenas testar a hipótese de que a irradiação ultra-sônica prévia facilita a absorção transcutânea do diclofenaco sódico na forma de gel de aplicação tópica, o que ficou claramente demonstrado, nas condições em que foi realizado.

O emprego concomitante de antiinflamatórios tópicos na forma de gel e ultra-som terapêutico até o momento utilizado de forma quase empírica, principalmente por fisioterapeutas, agora tem um forte potencial para a aplicação clínica, tendo em vista esta comprovação laboratorial de que a irradiação prévia da pele com ultra-som terapêutico facilita a penetração transcutânea de diclofenaco sódico na forma de gel tópico. 


\section{CONCLUSÃO}

Os resultados obtidos permitem concluir que o pré-tratamento da pele com ultra-som contínuo, na freqüência de $1 \mathrm{MHz}$ e intensidade de 0,5 $\mathrm{W} / \mathrm{cm}^{2}$, aplicado por 5 minutos, em áreas pré-determinadas de $225 \mathrm{~cm}^{2}$ de cada lado da região dorsal de voluntários, facilitou a penetração transcutânea de diclofenaco sódico, conforme mensuração da massa de diclofenaco realizada no plasma dos voluntários através de cromatografia líquida de alta eficiência. 


\section{ANEXOS}

Anexo A - Informações aos voluntários e termo de consentimento.

\section{TRABALHO DE INVESTIGAÇÃO CIENTÍFICA}

\section{Esclarecimentos e Consentimento}

TíTULO DA PESQUISA: Análise da influência do ultra-som terapêutico na penetração transcutânea de diclofenaco sódico em humanos sadios.

PESQUISADORA RESPONSÁVEL: Giovana de Cássia Rosim - CREFITO3/22050-F.

ORIENTADOR: Prof. Dr. Cláudio Henrique Barbieri.

INSTITUIÇÃO: Curso de Pós-graduação Interunidades BioengenhariaEESC/FMRP/IQSC-USP

\section{INFORMAÇÕES AO VOLUNTÁRIO E TERMO DE CONSENTIMENTO}

Esta pesquisa científica, que necessita da colaboração de voluntários, destina-se a medir a absorção de um medicamento através da pele, sob influência do ultra-som terapêutico. O medicamento utilizado é o diclofenaco Sódico, antiinflamatório que é o componente principal ou único de uma série de medicamentos, como por exemplo, o Voltaren Emulge ${ }^{\circledR}$, de uso corrente para o tratamento de processos inflamatórios. O poder antiinflamatório e analgésico do diclofenaco sódico utilizado por via oral ou injetável, bem como suas vias de metabolização e sua toxicidade já são suficientemente conhecidos, daí seu emprego praticamente universal no tratamento das doenças inflamatórias.

Os efeitos do ultra-som terapêutico, como o calor e a cavitação, são igualmente bem conhecidos de longa data, daí seu emprego como coadjuvante no tratamento de uma série de patologias traumáticas e 
inflamatórias. Um efeito que está sendo estudado mais recentemente é o da estimulação da absorção transcutânea de medicamentos, particularmente os antiinflamatórios, que podem ser introduzidos diretamente sobre os locais inflamados, mas produzindo nível sanguíneo suficiente para produzir efeitos analgésicos e antiinflamatórios.

O objetivo desta investigação científica é justamente estudar a concentração plasmática de diclofenaco sódico após aplicação do ultra-som terapêutico. Sua participação no trabalho é inteiramente voluntária e você deve ficar ciente de que:

1. O tratamento consiste na estimulação ultra-sônica terapêutica $(0,5$ $\mathrm{W} / \mathrm{cm}^{2}$ ) por 5 minutos em áreas pré-determinadas de $225 \mathrm{~cm}^{2}$ de cada lado da sua região dorsal, seguida da aplicação tópica de $2,5 \mathrm{~g}$ do Voltaren Emulge ${ }^{\circledR}$ nas mesmas áreas. Serão retiradas quatro amostras de pequeno volume $(3 \mathrm{~mL})$ do seu sangue, por punção venosa no antebraço com agulhas esterilizadas descartáveis, sendo uma antes da aplicação e três a intervalos de uma hora após a mesma.

2. Sua permanência no local será de cerca de três horas e meia em jejum.

3. O tratamento a que você estará sendo submetido, bem como a coleta de amostras de sangue não tem nenhuma finalidade terapêutica, sendo, portanto, desnecessário sob esse ponto de vista. Portanto, você tem a liberdade de retirar seu consentimento e deixar de participar do estudo, a qualquer momento, sem qualquer prejuízo a sua saúde.

4. Por outro lado, até onde se conhece, tanto o Voltaren Emulge ${ }^{\circledR}$ como o ultra-som terapêutico não produz qualquer efeito deletério ou danoso para a sua saúde, nas doses que serão empregadas.

Declaro que as informações acima foram por mim transmitidas ao voluntário signatário do presente termo, previamente à realização do tratamento. As eventuais dúvidas foram verbalmente esclarecidas. 
Giovana de Cássia Rosim

Pesquisadora Responsável

Data:

$\mathrm{Eu}$,

declaro

que

recebi as informações acima e as considerei suficientemente claras.

Declaro também que tenho pleno conhecimento dos direitos e das condições que me foram assegurados, a seguir relacionados:

1. A garantia de receber a resposta a qualquer pergunta ou esclarecimento de qualquer dúvida a respeito dos procedimentos, riscos, benefícios e de outras situações relacionadas com a pesquisa e o tratamento a que serei submetido.

2. A liberdade de retirar o meu consentimento e deixar de participar do estudo, a qualquer momento, sem que isso traga qualquer prejuízo àminha pessoa.

3. A segurança de que não serei identificado e que será mantido o caráter confidencial da informação relacionada a minha privacidade.

4. O compromisso de que me será prestada informação atualizada durante o estudo, ainda que esta possa afetar a minha vontade de continuar dele participando.

5. O compromisso de que serei devidamente acompanhado e assistido durante todo o período de minha participação no projeto.

6. O ressarcimento de eventuais despesas decorrentes da minha participação no projeto, a ser promovido pela própria pesquisadora responsável, Giovana de Cássia Rosim. 
7. Que o ressarcimento de eventuais despesas, bem como a indenização, a título de cobertura material, para reparação de danos imediatos ou tardios, decorrentes de minha participação na pesquisa, será feita pela própria pesquisadora responsável, Giovana de Cássia Rosim, não cabendo ao Hospital das Clínicas de Ribeirão Preto, ao Instituto de Química de São Carlos e ao Laboratório de Análises Clínicas Eugênia Cabianca, qualquer responsabilidade quanto aos referidos pagamentos.

Declaro, ainda, que concordo inteiramente com as condições que me foram apresentadas e que, livremente, manifesto a minha vontade em participar do referido projeto.

(assinatura do voluntário)

Pirassununga, de. .de 2002. 
Anexo B - Interrogatório e inspeção da pele.

TRABALHO DE INVESTIGAÇÃO CIENTíFICA - História Médica

TíTULO DA PESQUISA: Análise da influência do ultra-som terapêutico na penetração transcutânea de diclofenaco sódico em humanos sadios.

PESQUISADORA RESPONSÁVEL: Giovana de Cássia Rosim ORIENTADOR: Prof. Dr. Cláudio Henrique Barbieri

INSTITUIÇÃO: Curso de Pós-graduação Interunidades BioengenhariaEESC/FMRP/IQSC-USP

HISTÓRIA MÉDICA E INSPEÇÃO DA PELE

- Dados Pessoais:

Nome:

Data de Nascimento:

Idade:

Sexo:

Peso:

Altura:

- EXAME FÍSICO (inspeção da pele):

\section{RESPONDA SIM OU NÃO:}

- É fumante?

- Consome bebidas alcoólicas?

- Ingere algum medicamento?

- Utilizou algum medicamento nos últimos 7 dias?

- Tem hipersensibilidade ou contra-indicação ao diclofenaco ou outro antiinflamatório?

- Possui antecedentes:

Cardíacos? Hepáticos?

Renais?

Pulmonares?

Gastrintestinais? Neurológicos?

Hematológicos?

Doenças dermatológicas?

- (Para mulheres): Resultado do teste de gravidez 
Anexo C - Aprovação do trabalho pelo Comitê de Ética em Pesquisa.

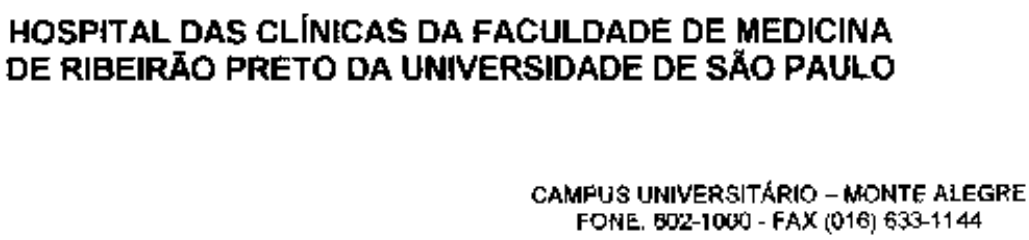

Ribeirăo Preto, 03 de outubro de 2002

Oficio no $\mathrm{n}^{\mathbf{0}} 2700 / 2002$

$\mathrm{CEP} / \mathrm{SPC}$

Prezada Benhora:

O trabalho intilulado "ANÁLISE DA INFLUENCIA DO ULTRA-SOM NA PENETRAÇĀO TRANSDERMICA DE Diclofenaco sódrco", foi analisado pelo Comitč de Ética em Pesquisa, em sua $140^{\circ}$ Rcuniāo Ordinária realizada em 30/09/2002, e enquadrado na categoria: APROVADO, de acordo com o Processo HCRP $n^{\circ} 5486 / 2002$.

Aproveito a oportunidade para apresentar a Vossa Senhorik protestos de estima e consideraçāo.

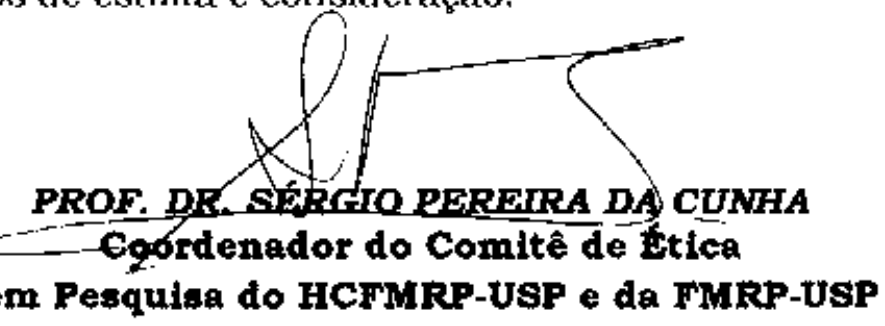

Ilustríssima Senhora

GIOVANA DE CASSIA ROSIM

Bioengenharia Interunidades - Escola de Engenharia - FMRP-USP

Instituto Química Sāo Carlos

Èm māos 


\section{REFERÊNCIAS BIBLIOGRÁFICAS}

ASANO, J.; SUISHA F.; TAKADA M.; KAWASAKI N.; MIYAZAKI, S. (1997) Effect of pulsed output ultrasound on the transdermal absorption of indomethacin from an ointment in rats. Biol Pharm Bull, v.20, n.3, p.288-91.

BARROS JR, E. A. (2001) Os efeitos do ultra-som na cicatrização de tendões flexores de coelhos após tenorrafia. Ribeirão Preto. 57p. Dissertação (Mestrado) - Escola de Engenharia de São Carlos / Faculdade de Medicina de Ribeirão Preto / Instituto de Química de São Carlos. Universidade de São Paulo.

BARRY, B. W. (2001) Novel mechanisms and devices to enable successful trasdermal drug delivery. European Journal of Pharmaceutical Science, v.14, p.101-114.

BENSON H. A. E.; McELNAY, J. C. (1994) Topical non-steroidal antiinflammatory products as ultrasound couplants: their potential in phonophoresis. Physiotherapy, v.80, n.2, p.74-6.

BYL, N.; McKENZIE, A.; HALLIDAY, B; WONG, T.; O'CONNELL J. (1993) The effects od phomophoresis with corticosteroids: a controlled pilot study. JOSPT, v.18, n.5, p.590-600.

DOCKER, M. F. (1987). A review of instrumentation available for therapeutic ultrasound. Physiotherapy, v.73, n.4, p.154-155.

DUNKY, A; KUROWSKI, M. (1992) Transdermal absorption of nonsteroidal anti- inflammatory drugs in rheumatoid arthritis patients: I. Diclofenac. Int J Clin Pharmacol Ther Toxicol. v. 30, n.11, p.479. 
DYSON, M. (1987). Mechanism involved in therapeutic ultrasound. Physiotherapy, v.73, n.3, p.116-20.

DYSON, M.; SUCKLING, J. (1978). Stimulation of tissue repair by ultrasound: a survey of mechanisms involved. Physiotherapy, v.64, n.4, p.105-108, april.

El-HADIDI T.; El-GARF (1991) Double-blind study comparing the use of Voltraen Emulgel ${ }^{\circledR}$ versus regular gel during ultrasonic sessions in the treatment of localized traumatic and rheumatic painful conditions. J Int Med Res, v.19, n.3, p.219-27.

FRENKEL, V; KIMMEL, E.; IGER, Y. (1999). Ultrasound-induced cavitation damage to external epithelia of fish skin. Ultrasound in Med. \& Biol., v.25, n.8, p.1295-303.

FRENKEL, V.; KIMMEL, E; IGER, Y. (2000). Ultrasound-induced intercellular space widening in fish epidermis. Ultrasound in Med. \& Biol., v.26, n.3, p.473-80.

ENWEMEKA, C. S. (1989). The effects of therapeutic ultrasound on tendon healing: a biomechanical study. American Journal Physical Medicine \& Rehabilitation, v.68, n.6, p.283-87.

GAN, B. S.; SHEREBRIN, M. H.; SCILLEY, C. G. (1995) The effects of ultrasound treatment on flexor tendon healing in the chicken limb. Journal of Hand Surgery, v.20, n.6, p.809-14, december

GIAGOUDAKIS, G.; MARKANTONIS S.L. (1998) An alternative highperformance liquid-chromatografic method for the determination of diclofenac and flurbiprofen in plasm. J. Pharm. Biomed. Anal., v.17, p.897-901. 
HAAR, G. T. (1987) Basic Physicis of Therapeutic Ultrasound. Physiotherapy. V. 73, n. 3, p.110-120.

HAAR, G. T. (1998). Principios eletrofísicos. In: KITCHEN, S; BAZIN, S. Eletroterapia de Clayton. São Paulo, Manole. Cap.1, p.23-30.

HAMED, M. R.; METWALLY, S. A.; EL-SHAFEY, A.; GENEIDI, A. S. (1994) Comparative percutaneous absorption of diclofenac emulgel preparations in normal volunteers. J. Drug Res. Egypt, v.21, n.1-2, p.133-41.

HOLLANDER M.; WOLFE, D. A. (1973). Nonparametric statistical methods. New York, John Wiley \& Sons.

HUI, X.; HEWITT, N. P.; MAIBACH, H. I.; SHAINHOUSE, J. Z.; WESTER, R. C. (1998) In vivo bioavailability and metabolism of topical diclofenac lotion in human volunteers. Pharmaceutical Research, v.15, n.10, p.1589-95.

JACKSON, B. A.; SCHWANE, J. A.; STARCHER, B. C. (1991) Effects of ultrasound therapy on the repair of Achilles tendon injuries in rats. Medicine and Science in Sports and Exercise, v.23, n.2, p.171-76, april.

JUNQUEIRA, L. C.; CARNEIRO, J. (1999) Histologia Básica. Rio de Janeiro, Guanabara-Koogan. Cap. 18, p.303-314: Pele e anexos.

KANH, J. (1991) Ultrasound in principles and pratice of electrotherapy. New York Churchill Livingstone, Cap.4, p.51-70.

KITCHEN, S.; PARTRIDGE, C. J. (1990). A review of therapeutic ultrasound. Physiotherapy, v.76, n.10, p.593-600. 
KLAIMAN, M. D.; SHRADER J. A.; DANOFF J. V.; HICKS J. E.; PESCE W. J. FERLAND J. (1998) Phonophoresis versus ultrasound in the treatment of common musculoskeletal conditions. Medicine \& Science in Sports \& Exercise by American College of Sports Medicine.

KUROWISK, M.; DUNKY A. (1992) Transdermal absorption of monsteroidal anti-inflammatory drugs in rheumatoid arthritis patients: I. Diclofenac. Int. J. Clin. Pharmacol. Ther. Toxicol., v.30, n.11, p.479.

LOW J.; REED, A. (2001) Eletroterapia explicada. 3 ed. São Paulo, Manole. Cap.6, p.187-228: Ultra-som terapêutico.

McELNAY J. C.; BENSON, H. A. E.; HARLAND, R.; HADGRAFT, J. (1993) Phonophoresis of Methyl Nicotinate: A Preliminary Study to Elucidate the Mechanism of Action. Pharmaceutical Research, v.10, n.12, p.1726-31.

MENEZES, D. F.; VOLPON, J. B.; SHIMANO, A. C. (1999) Aplicações de ultra-som terapêutico em lesão muscular experimental aguda. Rev. Bras. Fisiot, v.4, n.1, p.27-31.

MITRAGOTRI, S.; BLANKSCHTEIN, D.; LANGER, R. (1995) Ultrasoundmediated transdermal protein delivery. Science, v.269, n.5225, p.850-3.

MITRAGOTRI S.; EDWARDS D.; BLANKSCHTEIN, D.; LANGER R. (1995) A mechanistic study of ultrasonically-enhanced transdermal drug delivery. Journal of Pharmaceutical Science, v.84, n.6, p.697-706.

MÜLLER, M.; MASCHER H.; KIKUTA C.; SCHAFER S.; BRUNNER m.; DORNER G.; EICHLER H. (1997) Diclofenac concentrations in defined tissue layers after topical administration. Clin Pharmacol Ther., v.62, n.3, p.293-9. 
RADERMACHER, J.; JENTSCH, D.; SCHOLL, M. A.; LUSTINETZ, T.; FRÖLICH, J. C. (1991) Diclofenac concentrations in synovial fluid and plasm after cutaneous application in inflammatory and degenerative joint disease. Br. J. Clin. Pharmac., v.31, p.537-41.

ROBINSON, S. E.; BUONO, M. J. (1994). Effect of continuous-wave ultrasound on blood flow in skeletal muscle. Physical Therapy, v.75, n.2, p.145-9.

SENGUPTA, S.; VELPANDIAN, T.; KABIR, S. R.; GUPTA, S. K. (1998) Analgesic efficacy and pharmacokinetics of topical nimesulide gel in health human volunteers: double-blind comparison with piroxicam, diclofenac and placebo. Eur. J. Clin. Pharmacol., v.54, p.541-47.

SIOUFI, A.; POMMIER F.; BOSCHET F.; GODBILLON J.; LAVOIGNAT D.; SALLIERE D. (1994) Percutaneous absorption of diclofenac in health volunteers after single and repeated topical application of diclofenac emulgel. Biopharm Drug Dispos, v.15, p.441-449.

WILLIAMS, R. (1987). Production and transmission of ultrasound. Physiotherapy, n.73, p.113-16.

WU J.; CHAPPELOW J.; YANG J.; WEIMANN L. (1998). Defects generated in human stratum corneum specimens by ultrasound. Ultrasound in Med. \& Biol., v.24, n.5, p.705-10. 